\title{
Integrative approach in a safe by design context combining risk, life cycle and socio-economic assessment for safer and sustainable nanomaterials
}

\author{
Beatrice Salieri $^{\mathrm{a}, \mathrm{f}, *}$, Leire Barruetabeña ${ }^{\mathrm{b}}$, Isabel Rodríguez-Llopis ${ }^{\mathrm{b}}$, Nicklas Raun Jacobsen ${ }^{\mathrm{c}}$, \\ Nicolas Manier ${ }^{\mathrm{d}}$, Bénédicte Trouiller ${ }^{\mathrm{d}}$, Valentin Chapon ${ }^{\mathrm{d}}$, Niels Hadrup ${ }^{\mathrm{c}}$, Araceli \\ Sánchez Jiménez ${ }^{\mathrm{e}}$, Christian Micheletti ${ }^{\mathrm{f}}$, Blanca Suarez Merino ${ }^{\mathrm{f}}$, Jean-Marc Brignon ${ }^{\mathrm{d}}$, \\ Jacques Bouillard ${ }^{\mathrm{d}}$, Roland Hischier ${ }^{\mathrm{a}}$ \\ a Swiss Federal Laboratories for Materials Science and Technology (Empa), Technology and Society Lab, Lerchenfeldstrasse 5, 9014 St. Gallen, Switzerland \\ ${ }^{\mathrm{b}}$ GAIKER-IK4 Technology Centre, Parque Tecnológico, Ed. 20248.170, Zamudio, Bizkaia, Spain

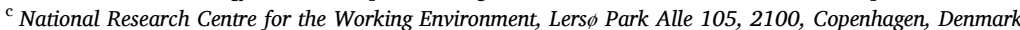 \\ d INERIS, Parc Alata, BP 2, 60550 Vernueil-en-Halatte, France \\ ${ }^{\mathrm{e}}$ Institute of Occupational Medicine (IOM) Research Avenue North, EH14 4AP Edinburgh, UK \\ ${ }^{\mathrm{f}}$ TEMAS Solutions GmbH, Lätterweg 5, 5212 Hausen, Switzerland
}

\section{A R T I C L E I N F O}

Editor: Dr. Bernd Nowack

\section{Keywords:}

Nanomaterials

Safe by design

Risk assessment (RA)

Life cycle assessment (LCA)

Socio-economic assessment (SEA)

\begin{abstract}
A B S T R A C T
Moving towards safe and sustainable innovations is an international policy ambition. In the on-hand manuscript, a concept combining safe by design and sustainability was implemented through the integration of human and environmental risk assessment, life cycle assessment as well as an assessment of the economic viability. The result is a nested and iterative process in form of a decision tree that integrates these three elements in order to achieve sustainable, safe and competitive materials, products or services. This approach, embedded into the stage-gate-model for safe by design, allows to reduce the uncertainty related to the assessment of risks and impacts by improving the quality of the data collected along each stage. In the second part of the manuscript, the application is shown for a case study dealing with the application of nanoparticles for Li-Ion batteries. One of the general conclusions out of this case study is that data gaps are a key aspect in view of the reliability of the results.
\end{abstract}

\section{Introduction}

Nanotechnology has become an integral part of our society with applications in many sectors of our economy such as healthcare, cosmetics, energy production, electronics, or environmental remediation. Its application in those fields offers new benefits and advantages compared to traditional technologies, and nanotechnology is nowadays increasingly seen as a potential solution to a wide range of environmental challenges, contributing to an urgently required sustainable development. Indeed, its application e.g. in green manufacturing and chemistry, clean energy technologies, $\mathrm{CO}_{2}$ conversion, capture and storage, and water purification (Babatunde et al., 2020; Diallo et al., 2013; Rodrigues et al., 2017; Serrano et al., 2009; Solanki et al., 2015) is in line with many of the seventeen UN Sustainable Development goals. ${ }^{1}$
But despite all these advantages and benefits, environmental, health and safety (EHS) issues of nanotechnology still require to be better elucidated and addressed (Falinski et al., 2018; Jacobs et al., 2010; Salieri et al., 2018). To do so, social, environmental and economic aspects related to such emerging technologies need to be assessed from an early innovation process phase and along their complete life cycle, i.e. from the extraction of the required resources to an adequate end of life treatment (Cinelli et al., 2016; Fleischer and Grunwald, 2008; Shapira and Youtie, 2015; Gottardo et al., 2021).

In the chemicals sector, this urge of pollution prevention together with concerns about potential risks to humans and to the environment lead in the 1990s to the establishment of the concept of Green Chemistry that aims "to design chemical products and process that reduce or eliminate the use or generation of hazardous substance" (Anastas, 1994). For this,

\footnotetext{
* Corresponding author at: Swiss Federal Laboratories for Materials Science and Technology (Empa), Technology and Society Lab, Lerchenfeldstrasse 5, 9014 St. Gallen, Switzerland.

E-mail address: beatrice.salieri@empa.ch (B. Salieri).

1 https://www.un.org/sustainabledevelopment/sustainable-development-goals/
} 
Green Chemistry adopts a set of 12 principles (such as e.g. prevention, design of safer chemicals, a less hazardous chemical synthesis, etc.), promoting environmentally friendly practices and solutions. Almost in parallel to Green Chemistry, the so-called "Benign-by-design" approach has been developed, ensuring the synthetic elegance of a chemical substance; i.e. the efficiency of the synthetic methodology, its economic viability and its environmental kindliness (Anastas, 1994). The criteria of Green Chemistry are "guidelines that provide the framework for sustainable design"(Anastas and Eghbali, 2010). Hence, one pillar of the Green chemistry is to design safer chemical across all stages of the chemical life cycle and to reduce the risk, by minimizing the hazard, from the earliest stage of the production process (Anastas and Eghbali, 2010; Zimmerman et al., 2020). Hazard refers thereby to toxicological (e.g. carcinogenicity), physical (e.g. explosivity) as well as global hazard (e.g. greenhouses gases) (Zimmerman et al., 2020). Life Cycle Assessment (LCA) is applied to support these Green Chemistry principles and in order to provide a sustainability metrics of new synthesis processes and/or new chemical products - i.e. evaluate global warming, ozone depletion, loss of biodiversity, (eco)toxicity (Cespi et al., 2020; Erythropel et al., 2018). The assessment of toxicological hazards of chemicals need to be included at early stage of the product development in order to minimize or eliminate toxicity (Anastas, 2016; Crawford et al., 2017; Anastas and Warner, 2005). The new paradigm for toxicology in the 21st century promotes the shift from a traditional, animal-based testing strategy towards new test strategies which rely on the mechanistic understanding of chemical toxicity (i.e. in vitro, in silico and omics methods testing as well as computation tests) (Andersen and Krewski, 2009). This paradigm has been adopted by "Green Toxicology", building upon the foundation of Green Chemistry principles, and aiming to develop safe chemicals, at early stage of their product development cycle in terms of both environmental and health impact (Crawford et al., 2017).

These principles were taken up in the field of nanotechnology too, under the heading of Safe(r)-by-Design, SbD (Yan et al., 2019; Morose, 2010; Gottardo et al., 2021). However, there is still a lack of consensus on what the SbD concept encompass in the nanotechnology industry (Sánchez Jiménez et al., 2020a). Despite this, SbD found already a wide spread in the area of nanotechnology as shown in Kraegeloh et al. (2018). The author identified there 36 scientific articles, published between 2011 and 2018, in which a variety of SbD strategies were applied to manufactured nanoparticle (NPs), such as design out of hazards, reduce releases, reduce bio-persistence, testing strategies for safety evaluation, material characterization, or the identification of riskhotspots for potential SbD approaches and pilot plant developments. In addition, SbD can be framed as a governance issue, where decision making is used to best reduce societal impact of new technologies while maximizing the benefits (Trump et al., 2020).

Since 2013, various European projects - grouped in the Nanosafety cluster - aimed to develop a Safe Innovation Approach (SIA) for nanomaterials. SbD for nanomaterials was initially defined within the FP7 project NANoREG (https://cordis.europa.eu/project/id/310584), where SbD was defined as a process enabling - at early stages - considerations of health and environmental safety in addition to functions in the design of a material, product or process (Gottardo et al., 2017). The development continued in the H2020 project "Prosafe" (https:// cordis.europa.eu/project/id/646325) and NanoReg ${ }^{2}$ (https://cordis. europa.eu/project/id/646221) by promoting the implementation of $\mathrm{SbD}$ in the research and development stage, and by integrating SbD within the Regulatory preparedness and Trusted Environment approaches in order to achieve an overall SIA.

In the context of this manuscript, the SbD concept according to the H2020 project NanoReg ${ }^{2}$ is applied (Gottardo et al., 2017; SoetemanHernandez et al., 2019; Dekker et al., 2020; Sánchez Jiménez et al., 2020a; Sánchez Jiménez et al., 2020b; OECD, 2020). There, the so-called "Stage-Gate Innovation Model" (Cooper, 2008) is used as described in Gottardo et al. (2017). At each stage of the innovation process (as shown in Fig. S1 in the supplementary materials) risks, functionality and costs are assessed to decide whether to continue, to stop or to re-design the innovation (Sánchez Jiménez et al., 2020a; OECD, 2020). SIA is proposed as a proactive system to minimize the gap between the pace of innovation and the pace of developed nano-risk governance (SoetemanHernandez et al., 2019). SIA combines this SbD approach, which recommends industry to integrate safety assessment at early stage of the innovation process, with the Regulatory Preparedness (RP), encouraging regulators to engage with innovators in order that regulations can keep pace with innovations. RP "aims to improve anticipation of regulators in order that they can facilitate the development of adaptable regulation that can keep up with the pace of knowledge generation and innovation of NMs and nano-enabled products" (Soeteman-Hernandez et al., 2019). Overall, SIA seek to enhance the ability of all stakeholders to address the safety assessment of innovations in a robust yet agile manner.

As further development, within the Nanoreg ${ }^{2}$ project the issues of safety (via SbD approaches) was combined with sustainability in order "to reduce potential health and environmental risks at an early phase of the innovation process, to enable consideration of safety aspects for humans and the environment in the design process of a product/materials, and to eliminate or minimize the risk of adverse effects along all life cycle stages of a produced material". Hence, SbD as understood in NanoReg ${ }^{2}$ implies the consideration of safety and sustainability not just as optional add-ons, but as integral parts of the actual design process as, "Safe-by-Design aims to reduce uncertainties and/or increase the human health and environmental safety from already early stages in the innovation process" (Dekker et al., 2020).

The objective being to create more sustainable and safer materials, production processes and products, leading finally to a safer use. Over the past 4 years, the project partners of the NanoReg ${ }^{2}$ project have developed a step-by-step process for the implementation of SbD to promote and foster a sustainable and safer production and application of nanotechnology. The step-by-step process aims to reduce uncertainties regarding safety while increasing the type of data requested as one moves along the innovation process, hence, moving from a qualitative assessment to a quantitative assessment. The description of the developed step-by-step process and of the tools chosen (i.e. control banding tools within the SIA toolbox, at each stage of the innovation process as reported in Table 1) is out of scope of this article. For a more detailed description please see, Soeteman-Hernandez et al., 2019; Sánchez Jiménez et al., 2020a; Dekker et al., 2020; Tavernaro et al., 2021, OECD, 2020). As recently, mentioned by Gottardo et al. (2021) the inclusion of sustainability in the SbD for nanomaterials is in line with EU-policy initiatives aiming to address safety and sustainability of material and product already at early stage of the design process. Therefore, such a comprehensive safe and sustainable approach needs to be applied from the initial planning steps (i.e. the business idea) until the actual market launch of the respective product (Kraegeloh et al., 2018; SoetemanHernandez et al., 2019; Dekker et al., 2020). The conceptual framework to identify safety from the early stage of the product development is a key aspect to ensure the sustainability of new products. In this context, dedicated tools and methods to assess the environmental and socioeconomic sustainability of products into SbD approaches can provide a broader picture of their sustainability (i.e. accounting for further sustainable metrics, such as e.g. global warming). Over the past decades numerous analysis tools and methods to tackle the various dimensions of sustainability have been proposed by the scientific community (Ness et al., 2007; Singh et al., 2012; National Research Council, 2011) and applied by industry (Trianni et al., 2019; Cespi et al., 2020). Among the most often used tools and approaches are Risk Assessment (RA), Life Cycle Assessment (LCA) and Socio-Economic Analysis (SEA). In the area of nanotechnology, such analysis tools are increasingly applied despite current limitations due to the (still) rather limited knowledge in terms of toxicity, environmental fate and distribution, and environmental and human exposure (Brignon, 2011; Fadel et al., 2015; Salieri et al., 2018; Sørensen et al., 2019; Cespi et al., 2020; Gottardo et al., 2021). 
Table 1

Data requirements for RA- and LCA-related calculations and the SIA toolbox (Soeteman-Hernandez et al., 2019) suggested at each business stage.

\begin{tabular}{|c|c|c|c|c|c|}
\hline & $\begin{array}{l}\text { STAGE } 1 \\
\text { BUSINESS IDEA }\end{array}$ & $\begin{array}{l}\text { STAGE } 2 \text { (TRL 2-3) } \\
\text { BUSINESS CONCEPT }\end{array}$ & $\begin{array}{l}\text { STAGE } 3 \text { (TRL 4) } \\
\text { LAB SCALE -PROTOTYPE } \\
\text { PRODUCTION }\end{array}$ & $\begin{array}{l}\text { STAGE } 4 \text { (TRL 5-8) } \\
\text { PILOT PRODUCTION }\end{array}$ & $\begin{array}{l}\text { STAGE } 5 \text { (TRL 9) } \\
\text { MARKET ENTRY }\end{array}$ \\
\hline $\begin{array}{l}\text { Material } \\
\text { characterization }\end{array}$ & \multicolumn{2}{|c|}{$\begin{array}{l}\text { (qualitative) description based on report, literature, } \\
\text { material safety data sheet, including risk label, } \\
\text { chemical composition, size, surface area, solubility, } \\
\text { density, particle form, and surface reactivity. } \\
\text { Respective bulk material can be use as reference. NP \& } \\
\text { product legal restrictions }\end{array}$} & \multicolumn{2}{|c|}{$\begin{array}{l}\text { Physical-chemical properties (Density, size, DLS, zeta potential, } \\
\text { dustiness, water solubility, hydrophobicity, dissolution rate }{ }^{1} \text {, } \\
\text { attachment and aggregation rate in media }{ }^{\text {a }} \text {, explosiveness and } \\
\text { flammability), potential release rate to the environmental } \\
\text { compartments (air, sediments, soils), dissolution rate in media }\end{array}$} & Legal compliance \\
\hline $\begin{array}{l}\text { Data for RA: } \\
\text { - Human hazard }\end{array}$ & $\begin{array}{l}\text { Bulk material or } \\
\text { similar NP (chemical } \\
\text { composition) can be } \\
\text { used as reference } \\
\text { - NP \& product } \\
\text { legislative } \\
\text { restrictions CLP } \\
\text { classification/ } \\
\text { Hazard properties, } \\
\text { REACH }\end{array}$ & $\begin{array}{l}\text { Bulk material or similar NP } \\
\text { (chemical composition) can } \\
\text { be used as reference } \\
\text { - CLP classification/ } \\
\text { Hazard properties }\end{array}$ & $\begin{array}{l}\text { - Experimental in vitro are } \\
\text { conducted and collected } \\
\text { from literature } \\
\text { - Measured physical-chemical } \\
\text { properties } \\
\text { - In vitro tests: inflammation, } \\
\text { oxidative stress, cytotoxicity, } \\
\text { genotoxicity \& mutagenicity } \\
\text { ocular and skin irritation, } \\
\text { bio-persistency in the body }\end{array}$ & $\begin{array}{l}\text { - Air-liquid interfaces for lung } \\
\text { toxicity } \\
\text { - More complex in vitro } \\
\text { experiments. } \\
\text { - In vivo experiments: inhalation, } \\
\text { genotoxicity, mutagenicity) } \\
\text { - Dermal toxicity } \\
\text { - Reprotoxicity }\end{array}$ & $\begin{array}{l}\text { Health surveillance of } \\
\text { workers }\end{array}$ \\
\hline $\begin{array}{l}\text { - Human } \\
\text { Exposure }\end{array}$ & \multirow{2}{*}{\multicolumn{2}{|c|}{$\begin{array}{l}\text { - Intended use and formulation } \\
\text { - Likelihood population exposed (children, health } \\
\text { related groups) along all the life cycle stages of the } \\
\text { NP or Nano- enable product } \\
\text { - Identification of exposure routes } \\
\text { - CLP assessment (SDS), REACH registration } \\
\text { Ecotoxicological potential accumulation/persistency } \\
\text { information (e.g. basic information on potential } \\
\text { ecotoxicity, read across data) }\end{array}$}} & $\begin{array}{l}\text { Release: Safe conditions of } \\
\text { use (modelled or read- } \\
\text { across), form of release, } \\
\text { dustiness, agglomerates } \\
\text { - Worker/indoor exposure }\end{array}$ & $\begin{array}{l}\text { Measured workers exposure } \\
\text { concentration for comparison } \\
\text { with OELs }\end{array}$ & $\begin{array}{l}\text { Periodic occupational } \\
\text { exposure assessments }\end{array}$ \\
\hline - Ecotoxicity & & & $\begin{array}{l}\text { - Toxicity (acute) test on } \\
\text { algae, crustacean and fish (in } \\
\text { vitro) } \\
\text { - In vitro test: cytoxicity } \\
\text { (metabolic activity), } \\
\text { membrane integrity, } \\
\text { lysosomal function } \\
\text { - Bio-persistency, bio- } \\
\text { durability }\end{array}$ & $\begin{array}{l}\text { - In vivo essential chronic } \\
\text { ecotoxicity tests: Algae growth } \\
\text { inhibition test, Daphnia acute } \\
\text { immobilization test, fish acute } \\
\text { toxicity test } \\
\text { - Depending on the production } \\
\text { volume: Toxicity on fish } \\
\text { development \& growth, } \\
\text { bbioaccumulation test }\end{array}$ & $\begin{array}{l}\text { Additional testing in } \\
\text { relation to the upscaling } \\
\text { of production: Daphnia } \\
\text { long term toxicity, fish } \\
\text { long term toxicity, bio- } \\
\text { accumulation (fish) }\end{array}$ \\
\hline Data for LCA & No action required & $\begin{array}{l}\text { Inventory data: Values on } \\
\text { estimated production chain } \\
\text { are collected (material \& } \\
\text { energy input; waste \& } \\
\text { emission) } \\
\text { Collection of toxicology } \\
\text { data from literature e.g. } \\
\text { PNEC/NOEC/NOAEL/ } \\
\text { LC50/EC50/ED50, } \\
\text { and of information about } \\
\text { transformation and } \\
\text { degradation process in } \\
\text { freshwater air, soil, } \\
\text { sediment }\end{array}$ & $\begin{array}{l}\text { LCI: values on lab scale } \\
\text { production chain are provided } \\
\text { (material \& energy input; waste } \\
\text { \&emission) } \\
\text { Workers/Indoor exposure: } \\
\text { Building volume, air exchange } \\
\text { rate, personal protective } \\
\text { equipment, inhalation rate, } \\
\text { number of people } \\
\text { (eco)-Effect: EC50 values on at } \\
\text { least two trophic levels } \\
\text { (interim) } \\
\text { (eco) -Exposure = 1 } \\
\text { (precautionary approach) } \\
\text { (human)-Effect: EC50 values } \\
\text { from in vitro test or in vivo test } \\
\text { (from RA based activity/ } \\
\text { literature/ read across data). } \\
\text { Interim Effect Factor is } \\
\text { calculated } \\
\text { (human) Exposure: indoor/ } \\
\text { outdoor calculated in } \\
\text { accordance with USEtox and } \\
\text { Walser et al. (2015) } \\
\text { Fate Factor water = calculated } \\
\text { according to simplified FF } \\
\text { matrixb.Fate Factor air indoor/ } \\
\text { outdoor: calculated according } \\
\text { to USEtox and Walser et al. } \\
\text { (2015) }\end{array}$ & $\begin{array}{l}\text { Inventory data: values pilot scale } \\
\text { production are provided } \\
\text { (eco)-Effect: EC50 values on three } \\
\text { trophic level } \\
\text { (human)-EF: interim values on in } \\
\text { vivo test (e.g. mouse) and in vitro } \\
\text { (from literature/ read across data } \\
\text { Fate Factor water/air outdoor: } \\
\text { USEtox4Nano } \\
\text { Fate Factor air: calculated } \\
\text { according to USEtox and Walser } \\
\text { et al. (2015) } \\
\text { (eco)-Exposure represent the } \\
\text { bioavailable (free species) fraction } \\
\text { of species }{ }^{4} \\
\text { (human) Exposure: indoor setting } \\
\text { (USEtox) }\end{array}$ & LCA updated \\
\hline $\begin{array}{l}\text { SIA Toolbox } \\
\text { suggested }\end{array}$ & $\begin{array}{l}\text { LICARA, } \\
\text { NanoRiskCat; CB } \\
\text { Nanotool; ANSES; } \\
\text { SPM }\end{array}$ & $\begin{array}{l}\text { LICARA; NanoRiskCat; } \\
\text { SPM; CB Nanotool; } \\
\text { DREAM; ANSES; Nano } \\
\text { FASE; REACH HIA; } \\
\text { CENARIOS } ® \text { Risks } \\
\text { management and } \\
\text { monitoring system }\end{array}$ & $\begin{array}{l}\text { LICARA (updated data), } \\
\text { NanoSafer; Stoffenmanager } \\
\text { Nano; SUNDS; Guidenano tool; } \\
\text { ART; dART; MARINA RA } \\
\text { Strategy; Nano solutions; ESIG- } \\
\text { GES-EGRET; NanoFASE; } \\
\text { REACH HIA; CENARIOS } \mathbb{R} \text {; } \\
\text { Nano CRED }\end{array}$ & $\begin{array}{l}\text { NanoSafer; SUNDS; GUIDEnano } \\
\text { tool; ART; RiskofDerm; ECETOC } \\
\text { TRA; FNN-BBN; ConsExpo Nano } \\
\text { Tool; MARINA RA Strategy; } \\
\text { SprayExpo model; BAMA indoor air } \\
\text { model; Nano FASE; Nano solutions; } \\
\text { AISE react; REACH HIA; Nano } \\
\text { CRED }\end{array}$ & $\begin{array}{l}\text { Australian guidance on } \\
\text { regulation impact } \\
\text { statement (RIS) cost- } \\
\text { benefit analysis; Societal } \\
\text { incubator; ECHA SEA } \\
\text { REACH; Golden Egg } \\
\text { Check; }\end{array}$ \\
\hline
\end{tabular}

\footnotetext{
a Meesters et al. (2014)

b Salieri et al. (2019)

c Salieri et al. (2015)
} 
The on-hand manuscript is focussing on the 5th step of the Step-bystep process for the implementation of $\mathrm{SbD}$ in the manufacturing of nanomaterials (Fig. S2). The Step-by step by process is described Sánchez Jiménez et al. (2020a); OECD (2020). In short, within the 5th step the efficiency of taken SbD measures is evaluated in order to ensure that those measures are indeed in line with the overall objective - i.e. getting a safer and sustainable NMs and/or nano-enabled products. For this, a systematic and integrative approach has been established that allows a consistent and comprehensive assessment of sustainability and safety issues and thus allows to promote and to foster a sustainable and a safe production and application of nanotechnology. Within the frame of the NanoReg ${ }^{2}$ project, this approach has been tested in six industrial case studies dealing with the production of NMs and/or nano-enabled products and services. The case studies were industry-led and toxicologists, expert in exposure and risk assessment were involved too (Sánchez Jiménez et al., 2020b). Section 2 of this manuscript describes-in detailthe combination of RA, LCA and SEA in the SbD context, and its various cornerstones. Section 3 summarizes one of these case studies in more details - the example of new anode materials for Li-ion batteries for electrical vehicles. The final section 4 summarizes the experiences from this application case and gives an outlook concerning next steps and open issues.

\section{Method - an integrative approach combining RA, LCA and SEA}

Within this 5th and last step of the comprehensive SbD scheme (Annex A, Fig. S2) reported in Sánchez Jiménez et al. (2020a) combining RA, LCA and SEA allows actually to ensure that a new development ends up not only as a safe but also a sustainable product. The integrative approach is shown in Fig. 1. The approach builds on an interactive, nested structure that needs to be applied each time when the implementation of SbD measures should be evaluated. Then the approach allows to evaluate if the applied measures lead really towards safer and more sustainable NMs and/or nano-enabled products. As shown in Fig. 1, this integrative evaluation starts always with the application of qualitative, semiquantitative or quantitative RA depending on the innovation stage (being the direct translation of the SbD requirements). If the outcomes of RA-based activities show an increasing risk in relation to the SbD action undertaken, new SbD measures need to be identified and applied - meaning that the respective RA analysis has to be performed again. Only when the RA analysis reveals that the undertaken SbD measures do not result in an increased risk anymore, the evaluation continues with an analysis of the environmental sustainability by a lean approach to LCA. Due to the preceding RA activities and their required data (such as data on worker exposure, ecotoxicity or human toxicity), nano-related toxicological impacts can also be assessed in this LCA step. Besides, the outcomes of this LCA allow in addition the identification of key aspects regarding resources and energy consumption, as well as produced waste volumes. Similar as for RA, as long as such LCA calculations results in a higher impact in one or more of the investigated impact categories, new SbD measures or a new mitigation strategy need to be identified and applied. In such a case, the entire analysis has to be repeated, i.e. the analysis has to start again with the RA step. In order to guide such a (further) revision of SbD measures and/or the mitigation strategy, a critical analysis of the aspects influencing the LCA results (i.e. energy consumption, emissions and waste) is performed on this level. Once RA and LCA show both better results - indicating that safety as well as the environmental sustainability are fulfilled - a similar procedure in relation to the economic sustainability is applied by the support of SEA. This integration of SEA as a third element results in supporting towards a better understanding of advantages and/or drawback of the introduction of new products and technologies in our society (for more details see, Brignon (2011)). However, this third element can only be performed from stage 3 of the innovation model on, as quantitative LCA results are a necessary input element for executing

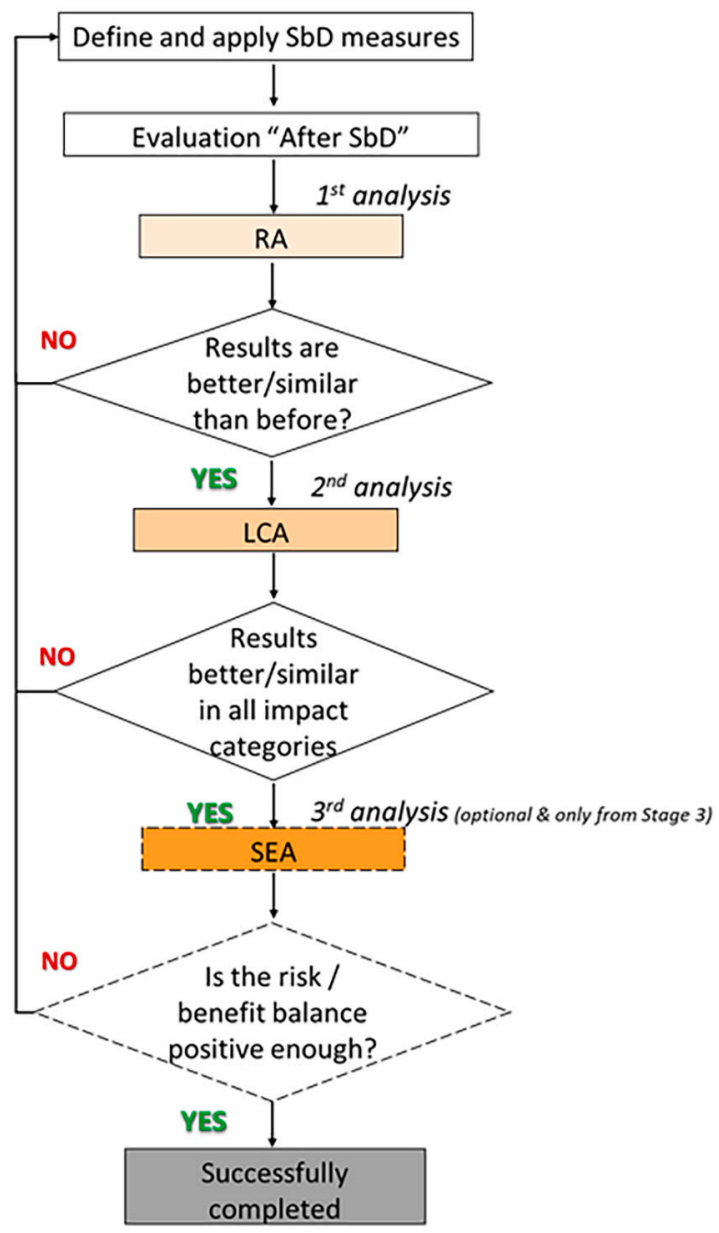

Fig. 1. Nested structure of the integrative approach for safe and sustainable products.

the subsequent SEA.

The "interactive and nested" application of RA, LCA and SEA allows in the end to ensure that each SbD measure is effectively a step towards a safer as well as a more sustainable material and/or product. The here implied, complementary and/or synergistic use of RA and LCA has been shown already (Barberio et al., 2014; Udo de Haes et al., 2006; Grieger et al., 2012; Kobayashi et al., 2015; Nishioka et al., 2002; Olsen et al., 2001). They represent numerous approaches, varying in relation to (1) the degree of integration, ranging from total separation to partial or full integration (Flemström et al., 2004); (2) the consideration of spatial and temporal differences (Udo de Haes et al., 2006); and (3) the way how hazardous risk information and LCA results are combined for decision making (Askham et al., 2013). Specifically for the field of nanotechnology, Grieger et al. (2012) analyzed studies combining RA and LCA and identified two main approaches: "LC-based RA" (i.e. a traditional RA approach, applied at various life cycle stage, and thus involving a lifecycle thinking approach) and "RA-complemented LCA" (there, a conventional LCA study is performed and supplemented by RA investigations in specific life-cycle steps - see e.g. Linkov and Seager, 2011). A third approach that can be found in recent publications consists in integrating RA and LCA at the methodological level (Breedveld, 2013; Sonnemann et al., 2019) - i.e. data and methods of RA are used in LCA. This third approach is here applied, allowing to consider in a consistent manner toxicity and exposure scenarios of NMs when addressing the toxic impact categories (Deng et al., 2017; Eckelman et al., 2012; Ettrup et al., 2017; Hischier and Walser, 2012; Miseljic and Olsen, 2014; Pini et al., 2016; Pourzahedi and Eckelman, 2015; Pu et al., 2016; Salieri et al., 2019; Salieri et al., 2015). Furthermore, this approach allows (1) 


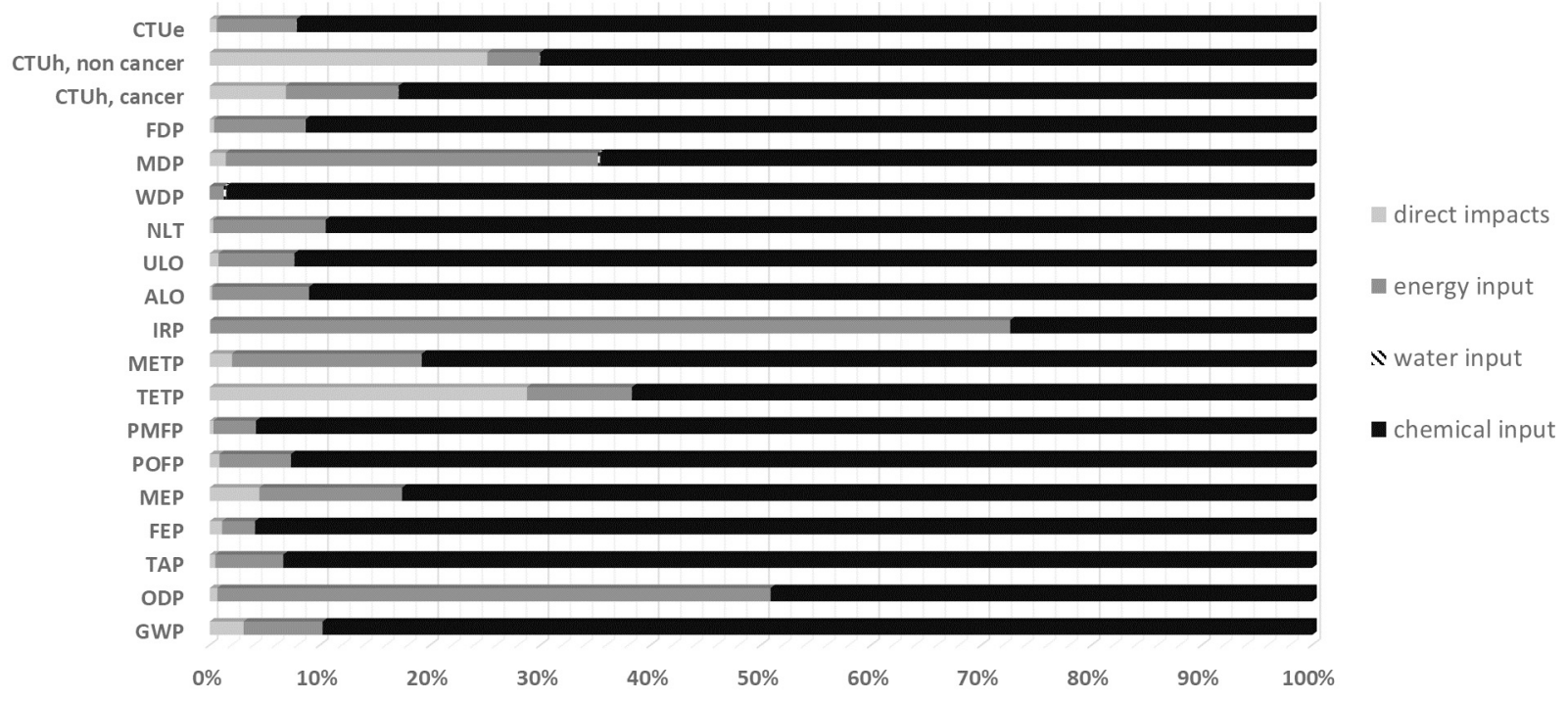

Fig. 2. Environmental impacts of the production of $1 \mathrm{~kg}$ of $S i 40 \mathrm{~nm}$. Reported are the relative contributions of the various inputs and of direct emissions (including the production of waste treated in the waste treatment activities). These results are shown using various ReCiPe midpoint indicators, except for the toxic impact categories, where the USEtox midpoint indicators are applied.

Reported ReCiPe midpoint factors are Ozone Depletion Potential (ODP), Natural Land Transformation (NLT), Marine Eutrophication Potential (MEP), Freshwater Eutrophication Potential (FEP), Particulate Matter Formation Potential (PMFP), Terrestrial Acidification Potential (TAP), Photochemical Oxidant Formation Potential (POFP), Terrestrial Ecotoxicity Potential (TETP), Urban Land Occupation (ULO), Water Depletion Potential (WDP), Mineral Resource Depletion Potential (MDP), Agricultural Land Occupation (ALO), Ionising Radiation Potential (IRP), Marine Ecotoxicity Potential (METP), Fossil Fuel Depletion Potential (FDP), and Global Warming Potential (GWP).

Reported USEtox midpoint indicator are Human Toxicity, non-cancer effect $\left(\mathrm{CTU}_{\mathrm{h}}\right.$, non-cancer), Human Toxicity, cancer effect $\left(\mathrm{CTU}_{\mathrm{h}}\right.$, cancer), Freshwater ecotoxicity $\left(\mathrm{CTU}_{\mathrm{e}}\right)$

to keep a life cycle perspective in the evaluation of potential hazards, (2) to make use of RA-based data in order to develop characterization factors for nano-related toxic impacts categories in a comprehensive and integrative manner along the entire life cycle, and (3) to cover at the same time more aspects than only (eco)-toxicity, like e.g. a contribution to global warming.

It is however obvious, that the application of the three different methods (RA, LCA, SEA) cannot be done in the same way in the different business stages of Cooper's stage-gate-model, used within the NANoREG SbD framework (Gottardo et al., 2017). The quality and quantity of data increases by moving from an early stage up to the last stage of a development. In early stages of the innovation process only qualitative data are available and thus, only qualitative approaches can be applied (Table 1). For example, at early stage of the innovation process (Steg 1 and Stage 2), a life cycle thinking approach is promoted by i.e. using screening tools such LICARA nanoSCAN (https://diamonds.tno. nl/\#licara). The approach supports to reflect regarding emission into the environment and exposure along all the life cycle stage of the new product or process. Table 1 shows a list of the (usually) available information at the various innovation stages (OECD, 2020; Sánchez Jiménez et al., 2020a) within the SbD approach. The suggested RAbased activities and tools require data (such as e.g. physical-chemical properties of the $\mathrm{NM}$ /nano-enabled products, human hazard exposure and ecotoxicity values) that are at the same time required within LCA in order to characterize the toxic impact categories. Specifically, those data can be applied for the calculation of the so-called Characterization Factors (CFs). In the present study, CFs of the examined NPs have been calculated in accordance with the USEtox model (http://usetox.org), the recommended model to quantify the potential impacts related to ecotoxicity and human toxicity (JRC-IES, 2011). USEtox provides CFs for organic and inorganic substances (Fantke et al., 2017), but no official version of CFs for NMs has been released so far, although in the last years, several authors developed such CFs for NMs (see e.g. Salieri et al., 2015; Walser et al., 2015; Pini et al., 2016; Pu et al., 2016; Deng et al., 2017; Ettrup et al., 2017; Salieri et al., 2019). Here, the USEtox4Nano model (Salieri et al., 2019) has been used to characterize the fate and distribution of NM in the environment.

In the past years, a variety of different nanomaterial-related control banding and risk-screening tools have been developed to deal with the lack of data in early innovation stages. Each requiring different input parameters and levels of information and resulting in different outputs (e.g. Stoffenmanager Nano (Van Duuren-Stuurman et al., 2012) and CB Nanotool (Zalk et al., 2019; Zalk et al., 2009)). Among non-nano-specific tools ConsExpo (at www.consexpoweb.nl) and Stoffenmanager (Marquart et al., 2008) as higher Tier Models for consumers and worker risk assessment, are available. All these tools have been developed for very different purposes, with different application domains, different inclusion criteria and e.g. the exposure assessments or the derived risk levels are based on different concepts and assumptions, resulting in outputs in different formats. Therefore, a list of identified, suitable tools is included in the step-by-step process, comprising (i) control banding tools that are simple, easy to use models that do not need large amounts of information and that give a qualitative output such as, e.g. the Precautionary Matrix for synthetic nanomaterials (Höck et al., 2018), NanoSafer (Krsitensen et al., 2010), NanoRiskCat (Hansen et al., 2011) as well as (ii) tools for a more comprehensive RA, requiring in the same time also more information and expertise in order to be used such as e.g. the Sustainable Nanotechnologies Project Decision Support System (SUNDS, at https://sunds.gd/) or the Weight of Evidence approach (Hristozov et al., 2014). In the end, the selection of an adequate tool depends on the stage of innovation and on the availability of the required data. In the frame of the NanoReg ${ }^{2}$ project, a detailed analysis of suitable RA-based tools has been conducted in order to determine common parameters for RA and LCA (more details see Annex B, Table S1 and Table S2). In vivo and in vitro experimental tests are included in the SdD framework (Sánchez Jiménez et al., 2020b) to assess the human and ecotoxicity of ENM i.e. genotoxicity test (OECD 487), comet assay, in vitro inflammation lung toxicity, skin irritation and ocular irritation (OECD 439, OECD 492), Micronucleus assay (OECD 487), cytotoxicity in fish cell lines (Kalaman et al., 2019), Daphnia magna chronic and acute tests 
(OECD 211; OECD 202). For more details see, Dekker et al. (2020), Sánchez Jiménez et al. (2020a), Tavernaro et al., 2021 The likelihood of occupational exposure is assessed following the exposure assessment strategy and criteria for classification of exposure in EN 17058, 2018. An indicative list of information of SIA toolbox suggested per stage of the innovation process is reported in Table 1 (more details are provided in Sánchez Jiménez et al., 2020a). The type of data that can be collected at each stage of the innovation process to assess the risks as well as the most suitable RA tools is not a prescriptive list and the order presented along the different stages is indicative. The information collected at each stage depends on the decisions made by the company based on the results from the previous stage and the level of uncertainty. For example, if at stage 2 there is a high concern with a specific physicochemical property (e.g. low solubility leading to bioaccumulation and persistence) the company may decide to perform some in vitro tests before moving to pilot production or change the specific physicochemical property to increase the solubility (as long as the NM functionality is not significantly affected) (Sánchez Jiménez et al., 2020a).

\section{Case study}

The applicability of the above described, integrative approach was demonstrated with an industrial case study about the generation of high performance Li-ion batteries by applying low toxic and low hazard materials.

A high level of maturity of the Li-ion battery technology has been already reached and they are widely used (Miao et al., 2019). However, the application of NMs in Li-ion batteries e.g. to improve their performance, is still in its infancy. Our partner company is investigating the use of Si-based NPs in order to substitute graphite in the anode of Li-ion batteries in order to achieve a higher performance (i.e. to allow for batteries with less weight for same energy content or more energy content in the same weight). Indeed, $\mathrm{Si}$ can double the storage capacity of the anode compared to graphite, while $\mathrm{Si}$ is suffering from less stability. To ensure the stability and to improve the long-term performance of such particles the company is coating the particle with carbon. In total, three NPs - a pure silicon nanoparticle ( $\mathrm{Si} 40 \mathrm{~nm}$ ), and two carbon coated silicon particles ( $\mathrm{Si} / \mathrm{C} 40 \mathrm{~nm}$ and $\mathrm{Si} / \mathrm{C} 75 \mathrm{~nm}$ ) - are currently produced by the company. Table 2 summarizes the key elements of the case study.

The case study is actually covering two distinguished parts, i.e. the manufacturing of the NPs and their application in Li-ion batteries, reflecting the twofold aims (and scope) of the entire innovation process by the company. The production of NPs is already at Stage 4 (i.e. at the pilot production), whereas their application in Li-ion battery is actually situated around Stage 3.

\subsection{Step 1 - Risk Assessment}

In accordance with the integrative approach (see Fig. 1), risk assessment was carried out as the first element. For this, an initial

Table 2

Key elements of the case study.

\begin{tabular}{|c|c|}
\hline Descriptor & Description \\
\hline Potential applications & $\begin{array}{l}\text { NP applied in the anode of Li-ion batteries for battery } \\
\text { electric vehicles (BEV) }\end{array}$ \\
\hline $\begin{array}{l}\text { Scope of the Safe by } \\
\text { Design } \\
\text { approach }\end{array}$ & $\begin{array}{l}\text { (i) Coating the silicon material with amorphous carbon and } \\
\text { increasing the particle size. } \\
\text { (ii) Application in Li-ion batteries }\end{array}$ \\
\hline Aim of the innovation & $\begin{array}{l}\text { (i) Evaluate the relevance of carbon coating and particle } \\
\text { size; } \\
\text { (ii) Obtain a more powerful Li-ion Battery }\end{array}$ \\
\hline $\begin{array}{l}\text { Nanomaterial/s } \\
\text { (before) }\end{array}$ & Pure silicon nanoparticles (Si $40 \mathrm{~nm}$ ) \\
\hline $\begin{array}{l}\text { Nanomaterial/s } \\
\text { (after) }\end{array}$ & $\begin{array}{l}\text { Carbon coated silicon nanoparticles of smaller ( } \mathrm{Si} / \mathrm{C} 40 \\
\mathrm{~nm}) \text { and larger size }(\mathrm{Si} / \mathrm{C} 75 \mathrm{~nm})\end{array}$ \\
\hline
\end{tabular}

screening of risk using e.g. control banding tools was performed in a first step. From the 33 tools specific to NPs included in the SIA Toolbox ${ }^{2}$ out of the project NanoReg ${ }^{2}$, the control banding tools NanoRiskCat, ${ }^{3}$ Precautionary Matrix for Synthetic nanomaterials ${ }^{4}$ and NanoSafer $1.1,{ }^{5}$ were identified as most suitable options for this case study. The selection of the most relevant risk screening tools, conducted by the NanoReg ${ }^{2}$ project partners, were based on the domain of interest (exposure, human hazard or overall risk), the physical-chemical information already known about the materials used as well as the additional information that was possible to generate within the case study group (Sánchez Jiménez et al., 2020a). A brief description of the selected tools is provided in the Supporting Information (Annex C). The results of their application in the case study can be summarized as following:

- NanoRiskCat: the exposure potential for workers, consumers and the environment and the effects on human health and the environment were assessed for $\mathrm{Si} / \mathrm{C} 40 \mathrm{~nm}$. The output of the tool is a medium exposure risk for all of them. The detailed results are listed in Annex B, Tables S3, to S5, in the supporting information.

- Precautionary Matrix for synthetic nanomaterials. For Si $40 \mathrm{~nm}$ the results for the production scenario are: 45 (precautionary need for employees) and 450 (precautionary need for employees -worst scenario). For the packaging scenario the precautionary score is: 45 (precautionary need for employees) and 4050 (precautionary need for employee -worst scenario). Similar results are calculated for $\mathrm{Si} / \mathrm{C}$ $40 \mathrm{~nm}$ and $\mathrm{Si} / \mathrm{C} 75 \mathrm{~nm}$.

- NanoSafer 1.1. The main element of the input parameter in the tool is the material dustiness index. For Si $40 \mathrm{~nm}, \mathrm{Si} / \mathrm{C} 40 \mathrm{~nm}$ and for Si/C $70 \mathrm{~nm}$ a dustiness index of $1163 \mathrm{mg} / \mathrm{kg}$, of $150 \mathrm{mg} / \mathrm{kg}$ and of $21 \mathrm{mg}$ / $\mathrm{kg}$ were calculated, respectively. For the scenario of production and packaging of Si $40 \mathrm{~nm}$ the high dustiness index returns in a high potential exposure risk and protection equipment and fume-hood, are highly recommended. For $\mathrm{Si} / \mathrm{C} 40 \mathrm{~nm}$ with a lower dustiness index, a lower potential exposure is returned by the tool. However, the hazard evaluation is shifted to a higher score compared with the score reported for Si $40 \mathrm{~nm}$. The cause for this is the conservative precautionary nature of the tool towards all materials with coatings. For $\mathrm{Si} / \mathrm{C} 70 \mathrm{~nm}$ is similar results to $\mathrm{Si} / \mathrm{C} 40 \mathrm{~nm}$ are calculated. Due to the lowest dustiness index of $\mathrm{Si} / \mathrm{C} 70 \mathrm{~nm}$ this $\mathrm{NP}$ received lowest score possible for potential exposure within the conservative nature of the NanoSafer tool.

In a second step, a weight of evidence (WoE) approach was applied. This approach encompasses SUNDS tool and traditional noncomputerized approach to cover toxicological effects with threshold. Non-threshold genotoxicity / carcinogenicity effects are considered by a non-computerized hazard assessment approach based only on published literature studies. Hazard characterization is focused on the inhalation route only. The in vitro skin irritation test (OECD guideline test 439) performed on the NPs, classified them as non-irritant, suggesting that the inhalation route is the most important from a hazard assessment point of view. Hazard assessment of the three NPs were performed using the following two approaches:

Approach A: In vivo test on $\mathrm{Si} 40 \mathrm{~nm}$ and $\mathrm{Si} / \mathrm{C} 40 \mathrm{~nm}$ were performed (more details are available in Annex $\mathrm{C}$ of the supplementary information). For Si/C $40 \mathrm{~nm}$ a LOAEL value of $2 \mathrm{mg} / \mathrm{kg}$ bw/day and hence a NOAEL of $1 \mathrm{mg} / \mathrm{kg}$ bw/day) are calculated. Whereas, for Si $40 \mathrm{~nm}$ a NOAEL value of $2 \mathrm{mg} / \mathrm{kg}$ bw/day is considered. For Si/C 40 a DNEL of

\footnotetext{
${ }^{2}$ https://www.siatoolbox.com/tool

3 http://nanodb.dk/en/nanoriskcat/

4 https://www.bag.admin.ch/bag/en/home/gesund-leben/umwelt-und-gesu ndheit/chemikalien/nanotechnologie/sicherer-umgang-mit-nanomaterialien/ vorsorgeraster-nanomaterialien-downloadversion.html

5 http://www.nanosafer.org/
} 
$0.2 \mathrm{mg} / \mathrm{m}^{3}$ and for Si $40 \mathrm{~nm}$ DNEL of $0.2 \mathrm{mg} / \mathrm{m}^{3}$ were calculated.

Approach B: Literature data using other NP of similar composition -such as $\mathrm{SiO}_{2}$ (crystalline form) and Carbon Black - are collected and used to perform the hazard assessment. Threshold values (i.e. NOAEL) and no-threshold genotoxicity /carcinogenicity effects data found in literature are converted into DNEL and DMEL (Derived minimal effect level) values by i) using a REACH combined safety factor of 25 and ii) by applying the toxicological values in SUNDS tool. The toxicological values, the derived DNEL and DMEL for $\mathrm{SiO}_{2}$ and Carbon black are reported in Table 3 (more details in Annex C of the supplementary information).

In conclusion, based on both approaches A and B a DNEL of $0.2 \mathrm{mg} /$ $\mathrm{m}^{3}$ could be suggested for all three materials. In contrast, the DMEL (carcinogenicity) values determined by Approach B suggest much lower limits of exposure, in the low microgram $/ \mathrm{m}^{3}$ range. The assessment here performed revealed a potential risk for the workers (Approach A) and suggests the worker's exposure (inhalation) should be kept within the range of microgram $/ \mathrm{m}^{3}$.

Concerning the comparison of the three nanomaterials, this showed that for $\mathrm{Si} / \mathrm{C} 40 \mathrm{~nm}$ there is some evidence (i.e. neutrophil influx and inflammatory cytokines in BAL) that those particles are more toxic than Si $40 \mathrm{~nm}$. However, the data do not point towards the carbon coating increasing the toxicity (Approach B). Concerning size of the NPs, the here performed hazard assessment did not point towards differences in toxicity due to this parameter. However, the influence of the size and surface area of the nanoparticle on their toxicity is well reported in the literature. Decreased size/increased surface area are associated with higher toxicity. However, considering evidence from literature, the toxicity is related to the small size of the particle (Braakhuis et al., 2014)-the selection of a larger particle would be safer than the selection

Table 3

The table reported the toxicity values reported in literature for $\mathrm{SiO}_{2}$ and carbon black and the DNEL and DMEL values.

\begin{tabular}{|c|c|c|c|c|}
\hline NP & $\begin{array}{l}\text { Value of dose } \\
\text { descriptors } \\
\text { reported in } \\
\text { literature }\end{array}$ & SUNDS & $\begin{array}{l}\text { DNEL } \\
\text { and } \\
\text { DMEL } \\
\text { values }\end{array}$ & Source \\
\hline $\mathrm{SiO}_{2}$ & $\begin{array}{l}\text { NOAEL }=2 \mathrm{mg} \text { / } \\
\mathrm{m}^{3} \\
\text { (Average value } \\
\text { calculated on } \\
\text { the basis of } \\
\text { literature } \\
\text { evidences) }\end{array}$ & $\begin{array}{l}\text { DNEL = 0.003-1 } \\
\mathrm{mg} / \mathrm{m}^{3} \\
\text { (lower/upper } \\
\text { confidential } \\
\text { limit) }\end{array}$ & $\begin{array}{l}\mathrm{DNEL}= \\
0.02 \\
\mathrm{mg} / \mathrm{m}^{3}\end{array}$ & $\begin{array}{l}\text { Arts et al., 2007, } \\
\text { Muhle et al., } \\
\text { 1995, Rossi et al. } \\
\text { 2010, Sayes et al., } \\
\text { 2010, Warheit } \\
\text { et al., } 1995\end{array}$ \\
\hline $\mathrm{SiO}_{2}$ & $\begin{array}{l}\text { NOAEL }=4 \mathrm{mg} / \\
\mathrm{m}^{3}\end{array}$ & $\begin{array}{l}\text { DNEL }= \\
0.02-3.4 \mathrm{mg} / \mathrm{m}^{3} \\
\text { (lower /upper } \\
\text { confidence limit) }\end{array}$ & $\begin{array}{l}\mathrm{DNEL}= \\
0.2 \mathrm{mg} / \\
\mathrm{m}^{3}\end{array}$ & ECHA database $^{a}$ \\
\hline $\mathrm{SiO}_{2}$ & $\begin{array}{l}\mathrm{LOAEL}=1 \mathrm{mg} / \\
\mathrm{m}^{3} \\
\mathrm{~T} 25=0.11 \mathrm{mg} / \\
\mathrm{kg} \text { bw/day }\end{array}$ & & $\begin{array}{l}\text { DMEL = } \\
0.004 \\
\mu \mathrm{g} / \mathrm{kg} \\
\text { bw/day } \\
\text { DMEL = } \\
0.06 \mu \mathrm{g} / \\
\mathrm{m}^{3}\end{array}$ & $\begin{array}{l}\text { Muhle et al., } \\
\text { 1995; Dybing } \\
\text { et al., } 1997\end{array}$ \\
\hline $\begin{array}{r}\text { Carbon } \\
\text { black }\end{array}$ & $\begin{array}{l}\text { NOAEL }=1 \mathrm{mg} / \\
\mathrm{m}^{3}\end{array}$ & $\begin{array}{l}\mathrm{DNEL}= \\
0.005-8.4 \mathrm{mg} / \\
\mathrm{m}^{3} \\
\text { (Lower /upper } \\
\text { confidence limit) }\end{array}$ & $\begin{array}{l}\mathrm{DNEL}= \\
0.04 \\
\mathrm{mg} / \mathrm{m}^{3}\end{array}$ & $\begin{array}{l}\text { Carter et al., } \\
\text { 2006; Driscoll } \\
\text { et al., 1996; Elder } \\
\text { et al., 2005; } \\
\text { Heinrich et al., } \\
\text { 1995; Mauderly } \\
\text { et al., } 1994\end{array}$ \\
\hline $\begin{array}{r}\text { Carbon } \\
\text { black }\end{array}$ & $\begin{array}{l}\text { LOAEL of } 11.6 \\
\text { and } 2.5 \mathrm{mg} / \mathrm{m}^{3} \\
\text { T25 of } 1.6 \text { and } \\
1.7 \mathrm{mg} / \mathrm{kg} \mathrm{bw} / \\
\text { day }\end{array}$ & & $\begin{array}{l}\text { DMEL = } \\
0.07 \mu \mathrm{g} / \\
\mathrm{kg} \mathrm{bw/} \\
\text { day. } \\
\mathrm{DMEL}= \\
1.0 \mu \mathrm{g} / \\
\mathrm{m}^{3}\end{array}$ & $\begin{array}{l}\text { Heinrich et al., } \\
\text { 1995; Mauderly } \\
\text { et al., } 1994\end{array}$ \\
\hline
\end{tabular}

a https://echa.europa.eu/home of a smaller particle, and thus point towards the larger Si/C $75 \mathrm{~nm}$ being safer than $\mathrm{Si} / \mathrm{C} 40 \mathrm{~nm}$.

Comparative risk assessment by means of (eco)-toxicity experimental tests were conducted on $\mathrm{Si} 40 \mathrm{~nm}, \mathrm{Si} / \mathrm{C} 40 \mathrm{~nm}$ and Si/C $75 \mathrm{~nm}$. Algal growth inhibition test (OECD 201), Daphnia magna acute immobilization test and Daphnia magna chronic toxicity test (OECD 211) revealed comparable (i.e. no effect; EC50 > $100 \mathrm{mg} / \mathrm{L}$ ) among the three particles. The human and eco-toxicity test results are reported Sánchez Jiménez et al. (2020b).

The risk assessment was performed on the level of the production of the NPs, evaluating the coating of the silicon materials with amorphous carbon and increasing the particle size. The RA was not performed on the application of such NP into Li-Ion battery (e.g. use phase of the battery) as no risk to the environmental and to human is likely during the use phase of batteries. Concerns can be raised regarding the end-oflife of the battery. However, as the application of NPs in Li-ion battery is still at an early stage, scarce data are available regarding the end-of life of new type of battery. Hence, we did not proceed with the RA of this life cycle stage and we assumed that the outcomes of the RA for the manufacturing (i.e. potential exposure for workers, toxicity profile of the NPs) can be consider valid also for the life cycle stage of end-of -life.

In conclusion, the RA activities do not show particular criticalities for the adopted SbD measures (i.e. carbon-coating and size) applied in the NPs under investigation. A comparable toxicity between all three NPs was observed; thus, the SbD measures are fulfilled, and we can proceed with the 2nd step, i.e. the LCA analysis.

\subsection{Step 2 - Life cycle assessment}

The second step of the integrative approach (Fig. 1) deals with performing an LCA study. All LCA activities are performed here in accordance with the respective ISO standards (ISO, 2006a, 2006b); the entire LCA analysis has been established with the LCA software Simapro v8, using the database ecoinvent v3.4 as background database. The LCA study has been performed using three different perspectives - i.e. the manufacturing of the three NPs, the application of these NPs in the anode of a Li-Ion battery, and the use of these NP-containing batteries in a battery-electric vehicle (BEV). All of this supports i) to evaluate the taken SbD measures by investigating the manufacturing of the three NP, but also ii) to extend the investigation to the application of such new NP in Li-Ion batteries. For the latter case, executing RA at level of the battery is considered here as not necessarily since the NPs are contained inside the battery. This LCA at level of the Li-Ion battery is still at the Prototype Level (Stage 3).

\subsubsection{Manufacturing of the three NPS}

Case-specific inventory data (material, energy used, waste and emission) covering the production process for each of the three NPs have been collected from the producer; due to confidentiality reasons, the detailed inventory data cannot be disclosed in this manuscript. The actual emissions of nanoparticles into the environment during the production stage have been estimated based on the results of the RA activities, resulting in a release of $0.01 \%$ of the nanomaterials into the indoor working environment during the production step. No direct and/ or indirect release of nanoparticles into the wastewater collection system is likely and therefore no such releases have been assumed.

Data from the RA-related activities above were used to support the inventory data set (i.e. emission into the environments, amount of product produced) and in order to characterize the toxicity impacts related to eventual nano-emission (i.e. used to developed CFs for impact category (freshwater ecotoxcity'). An overall picture of the RA-data integrated into the LCIA framework is provided in Table S1 and S2 in the Supporting Information. The CFs for toxic impact categories have been calculated in agreement with the USEtox requirements (please see Fantke et al., 2017 for more details in the calculation procedure to determine $\mathrm{CF}$ ). A description on the calculation of the CFs for the three 
NPs is reported in Annex D of the supporting information. The calculated interim CFs (within the impact category of Freshwater Ecotoxicity) show the same order of magnitude for each of the three NPs. The inventory data (material, energy used, waste and emission) collected for the life cycle stage of manufacturing are similar among the three NPs. Hence, a similar environmental performance for all three NP results in this case study. Fig. 3 shows the LCA result for the manufacturing of $S i 40 \mathrm{~nm}$. The functional unit for this step is " $1 \mathrm{~kg}$ of production of $\mathrm{Si} 40 \mathrm{~nm}$ ". As main drivers for all the impact categories under investigation, the chemical inputs followed by the energy consumed can be identified.

\subsubsection{Application of the NPs in the anode of a Li-ion battery}

The system boundaries of the LCA study performed in the second step consider the life cycle of a Li-ion battery without its actual use phase. As the application of Si-based NPs in Li-ion batteries is currently at a prototype level (i.e. at Stage 3), a rather low accuracy of the inventory data is observed. Nevertheless, a preliminary LCA could be performed in the sense of a "predictive" assessment of such a future nano-enable product, providing to the company already at an early stage of their business a first indication concerning potential risks and impacts, and help them to identify (ecological) "hot spots". Furthermore, it should be noted that the low level of maturity of the technology (i.e. prototype level) here under investigation can influence the LCA result. The here investigated system is composed of the different components (i.e. battery cell, BMS, cooling system components, and Packaging), the final assembly as well as the end-of-life treatment after the use of such a battery. While for the assembly into a complete Li-ion battery, inventory data published by Ellingsen et al. (2014) about an average Li-ion battery for vehicles have been used here, the composition of the different elements of the battery cell under investigation - i.e. anode, cathode (assuming a nickel manganese cobalt (=NMC) type), separator and electrolyte - is modelled with respective information from the industrial partner. The functional unit for this second step is " $1 \mathrm{kWh}$ of stored energy within a Li-ion battery". Fig. 4 shows the relative results of such a battery - relative in comparison to a battery with a similar weight, but containing a graphite anode.

Fig. 4 shows a worse environmental performance for such a "new" battery. As it could be observed there, none of the investigated impact categories results in a lower impact for the example of the NP-containing battery; all categories show a higher impact - ranging from just a few percentages (e.g. CTUe, METP, TETP, MDP) to almost three times higher impact (for WDP, IRP, ODP). These differences are due to the main components (i.e. cathode, anode and electrolyte) and/or additional, structural elements (i.e. separator, aluminium and plastic parts), as the the further elements and the battery assembly are similar for both investigated batteries. A contribution analysis of these elements in the battery cells on the impact category of GWP revealed that the anode with NPs shows a higher impact than the comparable graphite anode. In accordance with the integrative approach, others measures should be taken and the application should be evaluated again. It should be noted however, that the low level of maturity of the technology under investigation can influence the LCA result; especially when compared to a fully mature technology like here. Hence, these result of the LCA here have to be considered preliminary and they reflect only partially the actual Sbd measures taken on the level of NPs. Therefore, as a further step of this preliminary evaluation the use of such a NP-containing battery in a battery electric vehicle (BEV) has been investigated.

\subsubsection{Use of the battery in a battery electric vehicle}

In the third step, this new, Si-NP-containing battery is integrated into a battery electric vehicle (BEV) in order to evaluate the (ecological) consequences of such a BEV compared to traditional petrol- or dieselbased vehicles. As functional unit "driving over a distance of $1 \mathrm{~km}$ " is used for this third step of the LCA. The system boundaries are covering

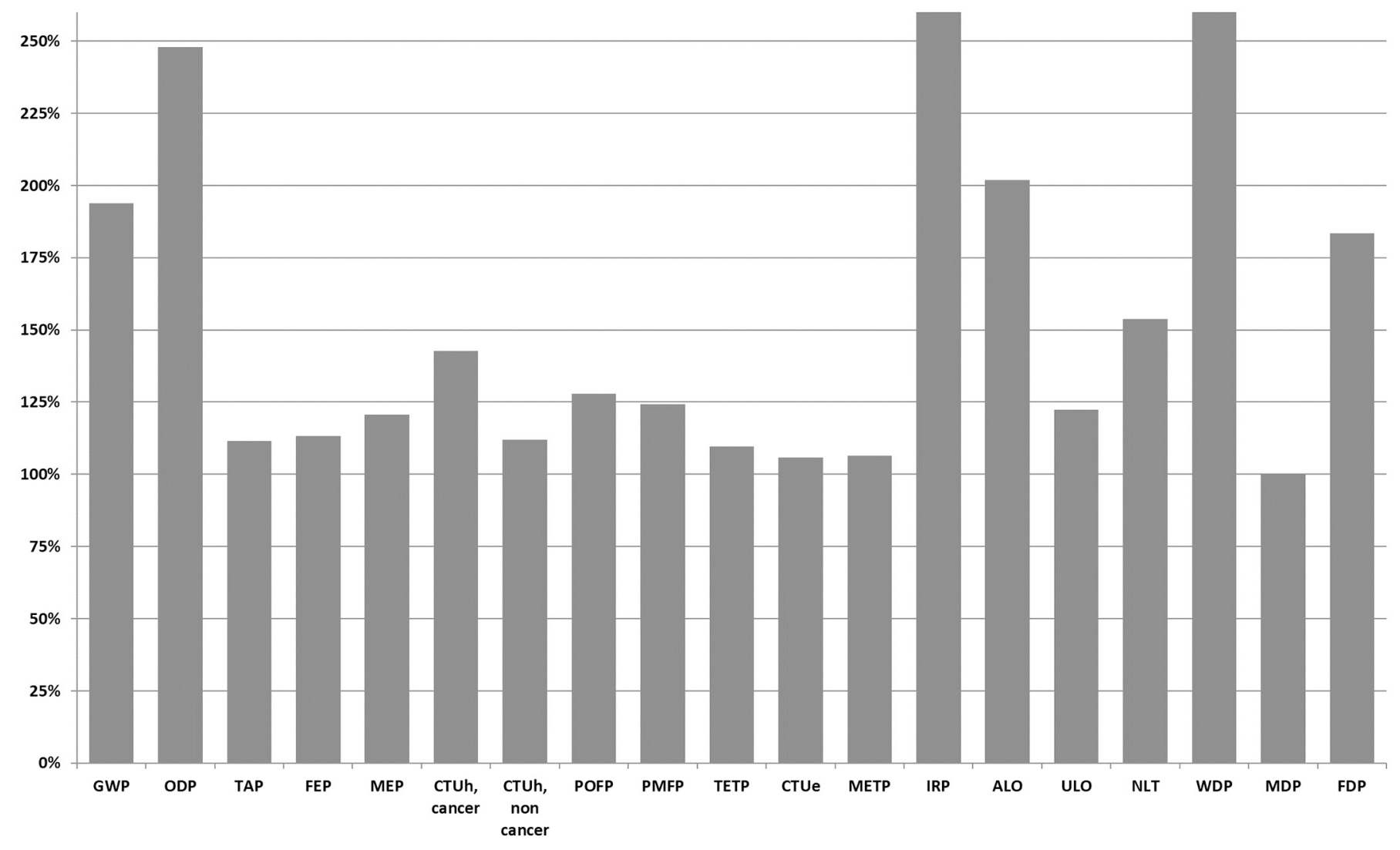

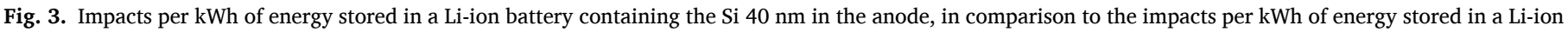
battery with a graphite-based anode (set to $100 \%$ for all indicators). Shown are the same midpoint indicators as in Fig. 2 . 


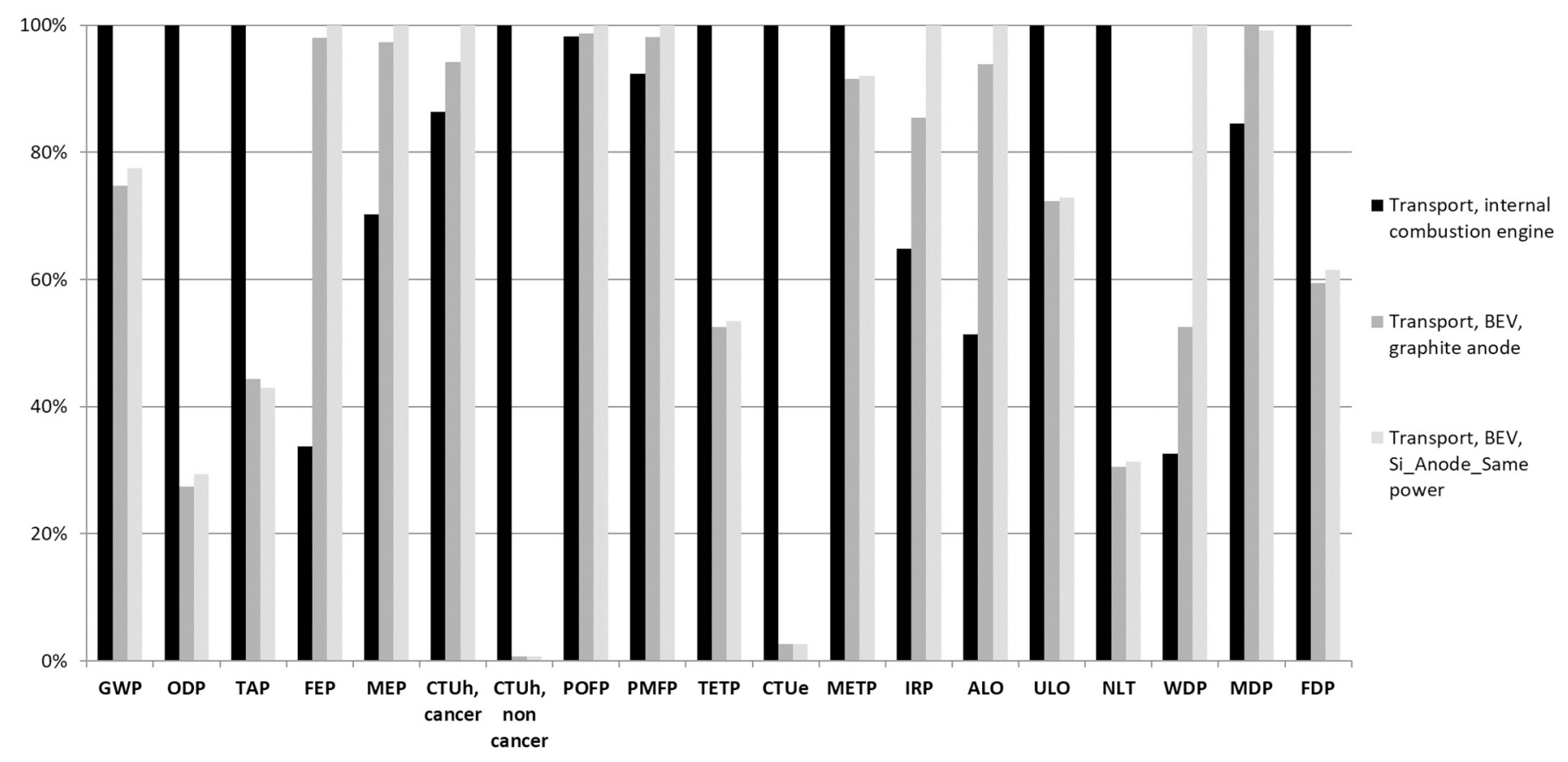

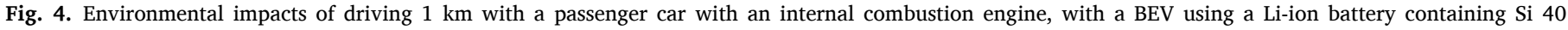

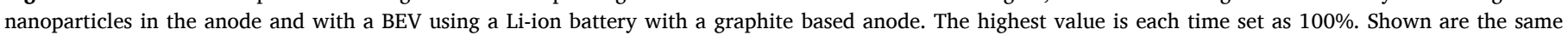
midpoint indicators as in Fig. 2.

the complete life cycle (i.e. production - use and maintenance - end-oflife treatment) of all components necessary for such a transport service i.e. the road, the vehicle as well as the related energy supply. Fig. 4 shows the results for the comparison of driving with a BEV containing either of the two types of batteries (from the preceding LCA step) to a petrol-based vehicle. These results show that, based on the here applied information, the use of Si-based NPs does not result in a better performance from the LCA point of view, especially when compared to the current material used in Li-ion batteries (i.e. graphite).

The LCA results on the application of Si-based NPs in Li-ion battery revealed that further investigation and/or improvement are required. Notable, the LCA case studies investigated a new Si-NP-containing battery, which is still at its prototype level hence, the results are influenced by the low maturity of the technology and by the low data quality.

Although the application of NPs in Li-ion battery is still in its infancy, the Li-ion battery technology in general is on a high level of maturity. Therefore, we proceed with a SEA study for the third step - i.e. these new Li-Ion batteries containing NP.

\subsection{Step 3 - Socio-economic analysis}

SEA focuses on comparing the risks and benefits of the introduction of Li-ion batteries containing Si $40 \mathrm{~nm}$ NPs in the market of personal light-duty BEV vehicles in France between 2020 and 2030. Have been excluded from the study: heavy-duty vehicles, commercial vehicles, two-wheeled vehicles, buses, and coaches. The analysis is based on the comparison of a baseline scenario without such NPs in batteries of BEV and a scenario entitled "Engineered Nanomaterials (ENS) scenario" in which BEV are equipped with Li-Ion batteries containing NPs. Here, we consider that due to the increase of capacity of this new battery type, the demand for light-duty BEV will increase at the expense of personal light diesel and gasoline vehicles. In both baseline and ENS scenarios, all new BEVs added to the fleet are assumed to fulfil the EURO 6d European standard.

According to the literature consulted, numerous factors such as purchase price, running costs, acceleration, fuel availability could affect BEV's future demand including the capacity of the battery (Windisch,
2013; EEA, 2016; Christensen et al., 2012). Consequently, the elasticity of the BEVs' demand is complicated to estimate and uncertain. In this study only the increasing capacity of the battery is considered. We have considered that an increasing vehicle autonomy due to the introduction NPs in batteries, could increase the number of kilometres driven with electric vehicles of $5 \%$ compared to the baseline scenario. To keep the total kilometres driven unchanged, the number of kilometres driven with ICEVs in the ENS scenario is reduced by $5 \%$ compared to the baseline scenario. The data reported in CITEPA (2018) regarding the kilometres driven per type of personal vehicles have been here used for the baseline scenario over the $2020-2030$ period. In order to assess and compare the two scenarios, we expand at the French market level the environmental costs and health impacts estimated by LCA along the complete life cycle for a vehicle, including for BEV the production of batteries and NPs, and the cost of innovation to develop these new NP batteries. Environmental impacts considered in the study are: climate change $\left(\mathrm{kg} \mathrm{CO}_{2} \mathrm{eq}\right)$, terrestrial acidification $\left(\mathrm{kg} \mathrm{SO}_{2} \mathrm{eq}\right)$, photochemical oxidant formation (kg NMVOC eq), particulate matter formation ( $\mathrm{kg}$ PM10) and NOx emissions ( $\mathrm{kg}$ NOx). Health impacts taken into consideration are numbers of cancers cases and non-cancers cases of illness. In a next step, these environmental and health impacts have then been monetized considering values present in the literature (Table 4). Results of the analysis suggest that these negative environmental and health impacts due to the use of NPs in batteries are negligible compared to the overall impacts of the entire vehicle production. However, due to a lack of data concerning the recycling and end-of-life treatment of this new battery type, we assume that there is no release of nanoparticles at those steps of the lifecycle, which tends to underestimate the potential risks of this nano-innovation. The cost of introduction of nanomaterials on batteries of vehicles, that is the cost for society to pass from the baseline scenario to the "Engineered Nanomaterials (ENS) scenario" is here represented as the cost of innovation and the cost of the modification of the vehicles fleet.

The cost of innovation which corresponds to the cost of introduction of new lithium-ion batteries on the market is assessed based on information from the manufacturer, as the difference between the unit production cost of a new lithium-ion battery for BEV (with Si $40 \mathrm{~nm} \mathrm{NP}$ ) and 
Table 4

Monetary values retained per category of impact in euros (2010).

\begin{tabular}{|c|c|c|}
\hline Impact & $\begin{array}{l}\text { Value in euros } \\
\text { (2010) }\end{array}$ & Source \\
\hline $\begin{array}{l}\text { Climate change (kg } \\
\left.\mathrm{CO}_{2}-\mathrm{eq}\right)\end{array}$ & $\begin{array}{l}\text { [32 in } 2020 \\
\text { and } 40 \text { in } \\
2030] \\
\text { [64 in } 2020 \\
\text { and } 80 \text { in } \\
2030]\end{array}$ & $\begin{array}{l}\text { Lowest values from the report High- } \\
\text { level commission on carbon prices ( } \\
\text { Stern and Stiglitz, 2017) } \\
\text { Highest values from the report of the } \\
\text { High-level commission on carbon } \\
\text { prices (Stern and Stiglitz, 2017) }\end{array}$ \\
\hline $\begin{array}{l}\text { Acidification }\left(\mathrm{kg} \mathrm{SO}_{2-}\right. \\
\text { eq) }\end{array}$ & 0,68 & $\begin{array}{l}\text { Delft Shadow Price (De Bruyn et al., } \\
\text { 2010) }\end{array}$ \\
\hline $\begin{array}{l}\text { Photo-oxidant } \\
\text { formation (kg } \\
\text { NMVOC-eq) }\end{array}$ & 1,4 & $\begin{array}{l}\text { Delft Shadow Price (De Bruyn et al., } \\
\text { 2010) }\end{array}$ \\
\hline $\begin{array}{l}\text { PM formation (kg } \\
\left.\mathrm{PM}_{10}-\mathrm{eq}\right)\end{array}$ & 22 & $\begin{array}{l}\text { Delft Shadow Price (De Bruyn et al., } \\
\text { 2010) }\end{array}$ \\
\hline $\begin{array}{l}\text { Impacts due to NOx } \\
\text { emissions (kg NOx) }\end{array}$ & 13 & $\begin{array}{l}\text { Update of the Handbook on External } \\
\text { Costs of Transport (Ricardo-AEA, } \\
\text { 2014) }\end{array}$ \\
\hline $\begin{array}{l}\text { Human toxicity } \\
\text { (cancer case) }\end{array}$ & 816,178 & $\begin{array}{l}\text { Valuing selected health impacts of } \\
\text { chemicals (ECHA, 2016) }\end{array}$ \\
\hline $\begin{array}{l}\text { Human toxicity (non- } \\
\text { cancer case) }\end{array}$ & 34,356 & (ECHA, 2014) \\
\hline
\end{tabular}

the unit production cost of conventional lithium-ion battery (with graphite) multiplied by the number of BEVs with new batteries in the scenario with NPs.

The material components of $262 \mathrm{~kg}$ battery pack with a lifetime of $100^{\prime} 000 \mathrm{~km}$ have been provided by the indus-trial nanomaterial manufacturer. Components prices are taken from the literature (Nelson et al., 2012; Patry et al., 2015) except for the cost of Si $40 \mathrm{~nm}$ NP that were given confidentially by the nanomaterial manufacturer. According to the literature, material costs for a conventional lithium-Ion battery represent $65 \%$ of the total cost of production and $66 \%$ for a lithium-ion combined with silicon alloy (Berckmans et al., 2017). Other costs are labour, cell assembly, module assembly and overhead. According to the nanomaterial manufacturer, the introduction of ENMs in lithium batteries, does not affect the battery production line, so the same share for other costs is applied for batteries with NPs. Costs of production obtained for $262 \mathrm{~kg}$ conventional lithium-ion battery and new lithium-ion battery are respectively $4^{\prime} 319,6$ and $4^{\prime} 980,8$ euros. This cost is multiplied by the number of BEV added to the fleet because of the autonomy improvement. Finally, the cost of innovation per year is comprised between 3 million in 2020 and 100 million in 2030. This estimation doesn't consider economy of scale for the production of batteries.

The cost of the modification of the fleet corresponds to the cost generated by the difference of the vehicle's mileages between the two scenarios. It has been estimated, as the additional costs of driving kilometres with BEV instead of ICEV. Kilometres driven by BEV substituting kilometres of diesel vehicles or petrol vehicles are estimated using the following hypothesis. In 2020 , we have considered that $68 \%$ of kilometres drive by new BEV substitute kilometres drive by diesel vehicles and $32 \%$ by petrol vehicles. Percentages shift to $76 \%$ for diesel and $24 \%$ for petrol in 2030. Between 2020 and 2030 a linear progression of these share is considered. To estimate the total value of this change we have relied on the study (Rousseau et al., 2015) which provides Relevant Cost of Ownership (RCO) per $\mathrm{km}$ for diesel, petrol and electric vehicles. These estimations of RCO include investment costs (manufacturing costs, manufacturer mark-up), residual value (resale value), energy cost, fees, taxes, incentives or disincentives (bonus/malus), maintenance and repair costs. According to the article, for France, RCO per kilometres for a diesel vehicle is 0,29 euro, for a petrol vehicle it is 0,32 euro and for a $\mathrm{BEV}$ it is 0,28 euro. These RCOs have been estimated for 2020 and are expressed in euro (2010).

To compare the two scenarios over the period 2020-2030 an "Environmental Net Present Value" (Env-NPV) has been calculated including economic impacts as well as monetized environmental and health impacts, considered by this study, by discounting costs and benefits using $4 \%$ for social discount rate and $8 \%$ for financial discount rate. Monetary values from the literature selected for this study are presented in the Table 4 below.

Among impacts monetized, climate change is the most important with NOx emissions. Benefits regarding climate change due to emissions of $\mathrm{CO}_{2}$ avoided has been estimated between 8 and 16 million in 2030 and 8 million for impact due to NOx emissions avoided. Although there are environmental benefits because of the modification of the fleet simulated due to the introduction of new batteries with a better autonomy, the Env-NPV estimated is negative. Which means that, in the mid-term following the introduction of ENMs in BEV, social costs would be greater than environmental benefits. More, this economic indicator is negative while end of life of batteries potential impacts has not been included in the study due to a lack of information. Lastly, these results must be considered with caution due to the assumption of constant costs for NMMs and energy and the absence of economy of scale to produce batteries. Given that $\mathrm{CO}_{2}$ avoided is the biggest environmental impact of this SEA, we realized a sensibility analysis for this parameter in order to estimate the monetary value of $\mathrm{CO}_{2}$ the society must consider making the Env-NPV positive. Env-NPV becomes positive when $\mathrm{CO}_{2}$ is valued at least 200 euros (in euros 2010) per ton of $\mathrm{CO}_{2}$ on average between 2020 and 2030, which correspond approximately to 3 times the highest value from Stern and Stiglitz (2017), but which are consistent with other value reported in literature (Matthey and Bünger, 2019; Quinet, 2019).

\section{Conclusions}

Within the on-hand manuscript, we combined in a meaningful and stepwise way RA, LCA and SEA, resulting in a coherent approach that (i) supports SbD efforts, and (ii) guides industry in a structured way to perform both, the safety and the sustainability evaluations along such a development process. Thus, the developed approach can be characterized as a nested and iterative process. Here, the implemented Cooper's Stage-Gate model (Soeteman-Hernandez et al., 2019; Tavernaro et al., 2021), as proposed within NanoReg ${ }^{2}$, was used as it provides a conceptual and operational map for moving new product from idea to launch (Cooper, 2008). Our integrative approach, embedded into the stage gate model for $\mathrm{SbD}$, aims to reduce the uncertainty related to the assessment of risks and impacts by improving the quality of data collected at each stage. In early development stages (i.e. stages 1 to 2) a lot of information is lacking and risk screening tools provide only qualitative or semi-quantitative data (Table 1). Hence, many estimations (e.g. in relation to emissions, exposure, etc.) are necessary to model a complete life cycle within a (often simplified) LCA study. Nevertheless, such RA and LCA results, although continuing to have a big uncertainty, could already support the decision-making process by identifying hot spots as well as points for improvement where (further) SbD measures could be applied. In the subsequent development stages 3 and 4 , where the quality and the quantity of data increases, quantitative values are used for the assessments and the resulting uncertainty of the outcomes gets reduced. However, even at these stages, data gaps can still occur especially related to (i) emissions and exposure data on downstream phases (e.g. use, but in particular the end-of-life stage) due to current scientific and practical limitations, and (ii) in vivo toxicological data, recommended to be gathered at these stages, as such assays are sometimes not performed due to the lack of legal obligations (e.g.in case of production lower than 1 ton), also, toxicological assay are very expensive and this can be a barrier to the toxicological evaluation. We agree with the notion that the on-line tools may require inclusion of some specialized data were an SME would need expert assistance. Either to generate needed data or locate proxy data from the literature. However, it may well be a small price to pay if results suggest modifying a otherwise hazardous product already at an early stage of development. Overall, the application of the here proposed integrative approach could still contain significant uncertainties in its results. Here, this approach 
has been tested in the frame of a case study dealing with the production and application of NPs in Li-Ion batteries. The safe by design pillars involved are a safe product (comparison of products properties) (Stage 4) and a safe use within batteries (Stage 3), reflecting the twofold aims of the entire innovation process. The approach revealed that the taken Sbd measurements, i.e. coating and increasing the size of NP, do not cause any increased risk and the LCA results showed as similar environmental profile of the NPs under investigation. Although the application of NPs in Li-ion battery is still in its infancy, LCA and SEA were performed. The LCA was affected by the low accuracy of the inventory data, due to the fact that the production of such batteries is at a prototype level (Stage 3) only. The SEA suggested that the environmental and health impacts due to the use of NPs in batteries are negligible compared to the overall impacts of the entire vehicle production. However, these SEA results must be considered with caution due to the assumptions taken to carry out the study, mainly due to the absence of economy of scale to produce batteries. This test of the various elements of the approach has shown that data gaps are indeed a key aspect in view of the reliability of the results. Another issue of concern for a general use by industry is the fact, that some of the described tools and calculation procedures require a high level of very specialized expertise. Therefore, further developments should take this into account to achieve even more simplified methodologies. More, the implementation of the NanoReg ${ }^{2}$ SbD framework was tested through six industrial case studies. Several advantages were shown through the case studies i.e. the Sbd can be applied to the three safety pillars (safety of product, safety of process, and safety of use) of the value chain and that safety can be designed for at early stages. On the other hand, the case studies revealed the difficulty of acquiring the necessary data to quantitatively evaluate risks and the to address the environmental sustainability, not only at the early-stage gates but also throughout the whole value chain. The economic costs for companies, especially SMEs, of adopting such a safe and sustainable by design approach (as it is sketched out here) have not been addressed in the frame of the underlaying European project. It is in the same time undoubtedly, that the here described approach is a step forward to include and combine the issues of sustainability and safety within an overarching approach, allowing to have a maximum of synergies between the various topics (i.e. safety and sustainability) and thus reduce the related costs to a minimum. Notable, various European research project such as, for example, SUNSHINE (https://www.h2020sunshine.eu/), GOV4NANO (https://www.gov4nano.eu/) are therefore on-going towards the same main goals, (i) by the development and implementation of simple, robust, and cost-effective Safe and Sustainable by Design (SSbD) approaches for industry and SME, and (ii) by the design and establishment of a Nanotechnology Risk governance Council (NRGC), representing an international umbrella for implementation of risk governance of nanotechnologies.

\section{Declaration of Competing Interest}

The authors declare that they have not known competing financial interests or personal relationships that could have appeared to influence the work reported in this paper.

\section{Acknowledgement}

This research has received funding from NanoReg ${ }^{2}$ project [grant number 646221] and from Porous4App project [grant number 686163] of the European Union's Horizon 2020 research and innovation program and from FFIKA, Focused Research Effort on Chemicals in the Working Environment, from the Danish Government.

\section{Appendix A. Supplementary data}

Supplementary data to this article can be found online at https://doi. org/10.1016/j.impact.2021.100335.

\section{References}

Anastas, P.T., 1994. Benign by design chemistry. Benign by Des. 2-22. https://doi.org/ 10.1020/bk-1994-0577.ch001.

Anastas, N.D., 2016. Connecting toxicology chemistry to ensure safer chemical design. Green Chem. 18, 4325-4331. https://doi.org/10.1039/C6GC00758A.

Anastas, P.T., Eghbali, N., 2010. Green chemistry: principle and practice. Chem. Soc. Rev. 39, 301-312. https://doi.org/10.1039/B918763B.

Anastas, N.D., Warner, J.C., 2005. The incorporation of hazard reduction as a chemical design criterion in green chemistry. Chem. Health Saf. 12 (2), 9-13. https://doi.org/ 10.1016/j.chs.2004.10.001.

Andersen, M.E., Krewski, D., 2009. Toxicity testing in the 21st century: bringing the vision to life. Toxicol. Sci. 107 (2), 324-330. https://doi.org/10.1093/toxsci/ kfn255.

Arts, J.H.E., Muijser, H., Duistermaat, E., et al., 2007. Five-day inhalation toxicity study of three types of synthetic amorphous silicas in Wistar rats and post-exposure evaluations for up to 3 months. Food Chem. Toxicol. 45 (10), 1856-1867.

Askham, C., Gade, A.L., Hanssen, O.J., 2013. Linking chemical risk information with life cycle assessment in product development. J. Clean. Prod. 51, 196-204. https://doi. org/10.1016/j.jclepro.2013.01.006.

Babatunde, D.E., Denwigwe, I.H., Babatunde, O.M., et al., 2020. Environmental and societal impact of nanotechnology. IEEE Access 8, 4640-4667. https://doi.org/ 10.1109/ACCESS.2019.2961513.

Barberio, G., Scalbi, S., Buttol, P., et al., 2014. Combining life cycle assessment and qualitative risk assessment: the case study of alumina nanofluid production. Sci. Total Environ. 496, 122-131. https://doi.org/10.1016/j.scitotenv.2014.06.135.

Berckmans, G., Messagie, M., Smekens, J., Omar, N., Vanhaverbeke, L., Van Mierlo, J., 2017. Cost projection of state of the art Lithium-ion batteries for electric vehicles up to 2030. Energies 10, 1314. https://doi.org/10.3390/en10091314.

Braakhuis, H.M., Park, M.V.D.Z., Gosens, I., et al., 2014. Physicochemical characteristics of nanomaterials that affect pulmonary inflammation. Part. Fibre Toxicol. 11, 18. https://doi.org/10.1186/1743-8977-11-18.

Breedveld, L., 2013. Combining LCA and RA for the integrated risk management of emerging technologies. J. Risk Res. 16 (3-4), 459-468. https://doi.org/10.1080/ 13669877.2012 .729526$.

Brignon, J.-M., 2011. Socio-economic analysis: a tool for assessing the potential of nanotechnologies. J. Phys. Conf. Ser. 304, 012069 https://doi.org/10.1088/17426596/304/1/012069.

Carter, J.M., Corson, N., Driscoll, K.E., et al., 2006. A comparative dose-related response of several key pro- and antiinflammatory mediators in the lungs of rats, mice, and hamsters after subchronic inhalation of carbon black. J. Occup. Environ. Med. 48, 1265-1278.

Cespi, D., Passarini, F., Neri, E., Cucciniello, R., Cavani, F., 2020. LCA integration within sustainability metrics for chemical companies. In: Maranghi, S., Brondi, C. (Eds.), Life Cycle Assessment Approaches in the Chemical Product Chain: Challenges, Methodological Apporaches and Application. Springer International publishing, Cham, pp. 53-73. https://doi.org/10.1007/978-3-030-34424-53.

Christensen, L., Kveiborg, O., Mabit, S.L., 2012. The market for electric vehicles - what do potential userswant. Paper Presented at 12th World Conference on Transportation Research, Lisbon, Portugal.

Cinelli, M., Coles, S.R., Sadik, O., et al., 2016. A framework of criteria for the sustainability assessment of nanoproducts. J. Clean. Prod. 126, 277-287. https:// doi.org/10.1016/j.jclepro.2016.02.118.

CITEPA, 2018. National inventories of air emissions in France: organisation and methodology. OMINEA report - 15th ed.

Cooper, R.G., 2008. Perspective: the Stage-Gate ${ }^{\circledR}$ idea-to-launch process-update, what's new, and NexGen systems*. J. Prod. Innov. Manag. 25 (3), 213-232. https:// doi.org/10.1111/j.1540-5885.2008.00296.x.

Crawford, S.E., Hartung, T., Hollert, H., et al., 2017. Green toxicology: a strategy for sustainable chemical and material development. Environ. Sci. Eur. 29 (1), 16. https://doi.org/10.1186/s12302-017-0115-z.

De Bruyn, S.M., Korteland, M.H., Markowska, A.Z., et al., 2010. Shadow Prices Handbook. Valuation and Weighting of Emissions and Environmental Impacts. Netherlands.

Dekker, S., Wijnhoven, S.W.P., Braakhuis, H.M., et al., 2020. Safe-by-design part I: proposal for nanospecific human helaths safety aspect needed along the innovation process. NanoImpact 18, 100227. https://doi.org/10.1016/j.impact.2020.100227.

Deng, Y., Li, J., Qiu, M., et al., 2017. Deriving characterization factors on freshwater ecotoxicity of graphene oxide nanomaterial for life cycle impact assessment. Int. J. Life Cycle Assess. 22 (2), 222-236. https://doi.org/10.1007/s11367-016-1151-4.

Diallo, M.S., Fromer, N.A., andJhon, M. S., 2013. Nanotechnology for sustainable development: retrospective and outlook. J. Nanopart. Res. 15 (11), 2044. https:// doi.org/10.1007/s11051-013-2044-0.

Driscoll, K.E., Carter, J.M., Howard, B.W., et al., 1996. Pulmonary inflammatory, chemokine, and mutagenic responses in rats after subchronic inhalation of carbon black. Toxicol. Appl. Pharmacol. 136, 372-380. https://doi.org/10.1006/ taap.1996.0045.

Dybing, E., Sanner, T., Roelfzema, H., et al., 1997. T25: A simplified carcinogenic potency index: description of the system and study of correlations between carcinogenic potency and species/site specificity and mutagenicity. Pharmacol. Toxicol. 80 (6), 272-279. https://doi.org/10.1111/j.1600-0773.1997.tb01973.x.

ECHA, 2014. Stated-Preference Study to Examine the Economic Value of Benefits of Avoiding Selected Adverse Human Health Outcomes due to Exposure to Chemicals in the European Union - Part 1 Sensitization \& Dose Toxicity. Charles University in Prague (Environment Center).. 
ECHA, 2016. Valuing Selected Health Impacts of Chemicals. Summary of the Results and a Critical Review of the ECHA Study.

Eckelman, M.J., Mauter, M.S., Isaacs, J.A., et al., 2012. New perspectives on nanomaterial aquatic Ecotoxicity: production impacts exceed direct exposure impacts for carbon Nanotoubes. Environ. Sci. Technol. 46 (5), 2902-2910. https:// doi.org/10.1021/es203409a.

EEA, 2016. Electic Vehicle in Europe. https://doi.org/10.2800/100230.

Elder, A., Gelein, R., Finkelstein, J.N., et al., 2005. Effects of subchronically inhaled carbon black in three species. I. Retention kinetics, lung inflammation, and histopathology. Toxicol. Sci. 88, 614-629. https://doi.org/10.1093/toxsci/kfi327.

Ellingsen, L.A.-W., Majeau-Bettez, G., Singh, B., et al., 2014. Life cycle assessment of a lithium-ion battery vehicle pack. J. Ind. Ecol. 18 (1), 113-124. https://doi.org/ 10.1111/jiec.12072.

EN 17058, 2018. Workplace Exposure - Assessment of exposure by inhalation of nanoobjects and their aggregates and agglomerates Nanomaterial grouping: Existing approaches and future recommendations.

Erythropel, H.C., Zimmerman, J.B., de Winter, T.M., et al., 2018. The green ChemisTREE: 20 years after taking root with the 12 principles. Green Chem. 20, 1929-1961. https://doi.org/10.1039/C8GC00482J.

Ettrup, K., Kounina, A., Hansen, S.F., et al., 2017. Development of comparative toxicity potentials of TiO2 nanoparticles for use in life cycle assessment. Environ. Sci. Technol. 51 (7), 4027-4037. https://doi.org/10.1021/acs.est.6b05049.

Fadel, T.R., Steevens, J.A., Thomas, T.A., et al., 2015. The challenges of nanotechnology risk management. Nano Today 10 (1), 6-10. https://doi.org/10.1016/j. nantod.2014.09.008.

Falinski, M.M., Plata, D.L., Chopra, S.S., et al., 2018. A framework for sustainable nanomaterial selection and design based on performance, hazard, and economic considerations. Nat. Nanotechnol. 13 (8), 708-714. https://doi.org/10.1038/ s41565-018-0120-4.

Fantke, P., Bijster, M., Guignard, C., Hauschild, M., et al., 2017. USEtox ${ }^{\circledR} 2.0$ Documentation (Version 1). http://usetox.org.

Fleischer, T., Grunwald, A., 2008. Making nanotechnology developments sustainable. A role for technology assessment? J. Clean. Prod. 16 (8), 889-898. https://doi.org/ 10.1016/j.jclepro.2007.04.018.

Flemström, K.C., Carloson, R., Erixon, M., 2004. Relationships between life cycle assessment and risk assessment - potentials and obstacles. Swed. Environ. Prot. Agency. https://doi.org/10.1016/j.jempfin.2002.12.003.

Gottardo, S., Alessandrelli, M., Valeria, A., et al., 2017. NANoREG Framework for the Safety Assessment of Nanomaterials, EUR 28550 EN. https://doi.org/10.2760/ 245972 .

Gottardo, S., Mech, A., Drbohlavovà, J., et al., 2021. Towards safe and sustainble innovation in nanotechnolgy: state-of-play for smart nanomaterials. NanoImpact 21, 100297. https://doi.org/10.1016/j.impact.2021.100297.

Grieger, K.D., Laurent, A., Miseljic, M., et al., 2012. Analysis of current research addressing complementary use of life-cycle assessment and risk assessment for engineered nanomaterials: have lessons been learned from previous experience with chemicals? J. Nanopart. Res. 14 (7), 958. https://doi.org/10.1007/s11051-0120958-6.

Hansen, S.F., Baun, A., Jensen, K.A., 2011. NanoRiskCat - a conceptual decision support tool for nanomaterials. Danish Ministry of the Environment. Environmental Project, No. 13722011.

Heinrich, U., Fuhst, R., Rittinghausen, R., et al., 1995. Chronic inhalation exposure of Wistar rats and two different strains of mice to diesel engine exhaust, carbon black, and titanium dioxide. Inhal. Toxicol. 7, 533-556. https://doi.org/10.3109/ 08958379509015211.

Hischier, R., Walser, T., 2012. Life cycle assessment of engineered nanomaterials: state of the art and strategies to overcome existing gaps. Sci. Total Environ. 425, 271-282. https://doi.org/10.1016/j.scitotenv.2012.03.001.

Höck, J., Behra, R., Bergamin, L., et al., 2018. Guidelines on the Precautionary Matrix for Synthetic Nanomaterials. Federal Office of Public Health and Federal Office for the Environment, Berne 2018, Version 3.1.

Hristozov, D.R., Zabeo, A., Foran, C., et al., 2014. A weight of evidence approach for hazard screening of engineered nanomaterials. Nanotoxicology 8 (1), 72-87. https://doi.org/10.3109/17435390.2012.750695.

ISO, 2006a. Environmental Management - Life Cycle Assessment - Principles and Framework. Geneva, International Standardization Organization (ISO), European Standard EN ISO $14^{\prime} 040$.

ISO, 2006b. Environmental Management - Life Cycle Assessment - Requirements and Guidelines. Geneva, International Standardisation Organisation (ISO), European Standard EN ISO 14'044.

Jacobs, J.F., van de Poel, I., Osseweijer, P., 2010. Sunscreens with titanium dioxide (TiO2) nano-particles: a societal experiment. Nano Ethics 4 (2), 103-113. https:// doi.org/10.1007/s11569-010-0090-y.

JRC-IES, 2011. ILCD Handbook General Guide for Life Cycle Assessment -Recommendations for Life Cycle Impact Assessment in the European Context-Based on Existing Environmental Imapct Assessment Models and Factors (Luexembourg).

Kalaman, J., Merinoc, C., Fernandez-Cruz, M., Navas, J.M., 2019. Usefulness of fish cell lines for the initial characterization of toxicity and cellular fate of graphene-related materials (carbon nanofibers and graphene oxide). Chemosphere 218, 347-358. https://doi.org/10.1016/j.chemosphere.2018.11.130.

Kobayashi, Y., Peters, G.M., andKhan, S. J., 2015. Towards more holistic environmental impact assessment: hybridisation of life cycle assessment and quantitative risk assessment. Procedia CIRP 29, 378-383. https://doi.org/10.1016/j. procir.2015.01.064.

Kraegeloh, A., Suarez-Merino, B., Sluijters, T., et al., 2018. Implementation of safe-bydesign for nanomaterial development and safe innovation: why we need a comprehensive approach. Nanomaterials 8 (4), 239. https://doi.org/10.3390/ nano8040239.

Krsitensen, H.V., Hansen, S.V., Holm, G.R., 2010. Nanopartikler i arbejdsmiljøet: Viden og inspiration om håndtering af nanomaterialer. Available from. http://nanosafer. i-bar.dk/media/Nanopartikler i arbejdsmiljoet samlet.pdf.

Linkov, I., Seager, T.P., 2011. Coupling multi-criteria decision analysis, life-cycle assessment, and risk assessment for emerging threats. Environ. Sci. Technol. 45 (12), 5068-5074. https://doi.org/10.1021/es100959q.

Marquart, H., Heussen, H., Le Feber, M., et al., 2008. 'Stoffenmanager', a web-based control banding tool using an exposure process model. Ann. Occup. Hyg. 52 (6), 429-441. https://doi.org/10.1093/annhyg/men032.

Matthey, A., Bünger, B., 2019. Methodenkonvention 3.0 zur Ermittlung von Umweltkosten, Kostensätze, Stand 02/2019. Umewelbundesamt. Availlable from. http://www.umweltbundesamt.de/publikationen.

Mauderly, J.L., Snipes, M.B., Barr, E.B., et al., 1994. Pulmonary toxicity of inhaled diesel exhaust and carbon black in chronically exposed rats. Part I: neoplastic and nonneoplastic lung lesions. Res. Rep. Health Eff. Inst. 68, 1-75 (discussion 77-97).

Meesters, J.A.J., Koelmans, A.A., Quik, J.T.K., et al., 2014. Multimedia modeling of engineered nanoparticles with SimpleBox4nano: model definition and evaluation. Environ. Sci. Technol. 48 (10), 5726-5736. https://doi.org/10.1021/es500548h.

Miao, Y., Hynan, P., von Jouanne, A., Yokochi, A., 2019. Current Li-Ion battery technologies in electric vehicles and opportunities for advancements. Energies 12 , 1074.

Miseljic, M., Olsen, S.I., 2014. Life-cycle assessment of engineered nanomaterials: a literature review of assessment status. J. Nanopart. Res. 16 (6), 2427. https://doi. org/10.1007/s11051-014-2427-x.

Morose, G., 2010. The 5 principles of "Desing for safer Nnaotechnology". J. Clean. Prod. 18 (3), 285-289. https://doi.org/10.1016/j.jclepro.2009.10.001.

Muhle, H., Kittel, B., Ernst, H., Mohr, U., Mermelstein, R., 1995. Neoplastic lung lesions in rat after chronic exposure to crystalline silica. Scand. J. Work Environ. Health 21, $27-29$.

National Research Council, 2011. Sustainability and the U.S. EPA. The National Academies Press, Washington, DC. https://doi.org/10.17226/13152.

Nelson, Paul A., Ahmed, Shabbir, Gallagher, Kevin G., Dees, Dennis W., 2012. Modeling the Performance and Cost of Lithium-Ion Batteries for Electric-Drive Vehicles, Third edition. https://doi.org/10.2172/1503280. United States.

Ness, B., Urbel-Piirsalu, E., Anderberg, S., et al., 2007. Categorising tools for sustainability assessment. Ecol. Econ. 60 (3), 498-508. https://doi.org/10.1016/j. ecolecon.2006.07.023.

Nishioka, Y., Levy, J.I., Norris, G.A., et al., 2002. Integrating risk assessment and life cycle assessment: a case study of insulation. Risk Anal. 22 (5), 1003-1017. https:// doi.org/10.1111/1539-6924.00266.

Olsen, S.I., Christensen, F.M., Hauschild, M., et al., 2001. Life cycle impact assessment and risk assessment of chemicals - a methodological comparison. Environ. Impact Assess. Rev. 21 (4), 385-404. https://doi.org/10.1016/S0195-9255(01)00075-0.

Organisation for Economic Co-operation and Development (OECD), 2020. Moving towards a Safe (r) Innovation for more sustainable nanomaterials and nano-enable products. Series on the Safety of Manufactured Nanomaterials No.96. ENV/JM/ MONO (2020)36/REV1.

Patry, G., Romagny, A., Martinet, S., Froelich, D., 2015. Cost modelling of lithium-ion battery clss for automotive applications. Energy Sci. Eng. 31 (1), 71-82. https://doi. org/10.1002/ese3.47.

Pini, M., Salieri, B., Ferrari, A.M., et al., 2016. Human health characterization factors of nano-TiO2 for indoor and outdoor environments. Int. J. Life Cycle Assess. 21 (10), 1452-1462. https://doi.org/10.1007/s11367-016-1115-8.

Pourzahedi, L., Eckelman, M.J., 2015. Environmental life cycle assessment of nanosilverenabled bandages. Environ. Sci. Technol. 49 (1), 361-368. https://doi.org/10.1021/ es504655y.

Pu, Y., Tang, F., Adam, P.M., et al., 2016. Fate and characterization factors of nanoparticles in seventeen subcontinental freshwaters: a case study on copper nanoparticles. Environ. Sci. Technol. 50 (17), 9370-9379. https://doi.org/10.1021/ acs.est.5b06300.

Quinet, A., 2019. La valeur de l'action pour le climat, Une valeur tutélaire du carbone pour évaluer les investissements et les politiques publiques. Rapport de la commission présidée par Alain Quinet, France Stratégie.

Ricardo-AEA, 2014. Update of the Handbook on External Costs of Transport.

Rodrigues, S.M., Demokritou, P., Dokoozlian, N., et al., 2017. Nanotechnology for sustainable food production: promising opportunities and scientific challenges. Environ. Sci. Nano 4 (4), 767-781. https://doi.org/10.1039/C6EN00573J.

Rousseau, A., Stehphans, T., Brokate, J., et al., 2015. Comparison of Energy Consumption and Costs of different Plug-in Electric Vehicles in European and American context. EVS28 International Electric Vehicle Symposium.

Salieri, B., Righi, S., Pasteris, A., et al., 2015. Freshwater ecotoxicity characterisation factor for metal oxide nanoparticles: A case study on titanium dioxide nanoparticle. Sci. Total Environ. 505, 494-502. https://doi.org/10.1016/j.scitotenv.2014.09.107.

Salieri, B., Turner, D.A., Nowack, B., et al., 2018. Life cycle assessment of manufactured nanomaterials: where are we? Nano Impact 10, 108-120. https://doi.org/10.1016/j. impact.2017.12.003.

Salieri, B., Hischier, R., Quik, J.T.K., et al., 2019. Fate modelling of nanoparticle releases in LCA: an integrative approach towards "USEtox4Nano". J. Clean. Prod. 206, 701-712. https://doi.org/10.1016/j.jclepro.2018.09.187.

Sánchez Jiménez, A., Raquel Puelles, R., Marta Perez-Fernandez, M., et al., 2020a. Safe by Design Guidelines for the Nanotechnology Industry: The NanoReg2 Case Studies. [Manuscript submitted for publication to NanoImpact]. 
Sánchez Jiménez, A., Raquel Puelles, R., Marta Perez-Fernandez, M., et al., 2020b. Safe (r) by desing implementation in the nanotechnology industry. NanoImpact 20, 100267. https://doi.org/10.1016/j.impact.2020.100267.

Sayes, C.M., Reed, K.L., Glover, K.P., et al., 2010. Changing the dose metric for inhalation toxicity studies: short-term study in rats with engineered aerosolized amorphous silica nanoparticles. Inhal. Toxicol. 22 (4), 348-354. https://doi.org/10.3109/ 08958370903359992.

Serrano, E., Rus, G., andGarcía-Martínez, J., 2009. Nanotechnology for sustainable energy. Renew. Sust. Energ. Rev. 13 (9), 2373-2384. https://doi.org/10.1016/j. rser.2009.06.003.

Shapira, P., Youtie, J., 2015. The economic contributions of nanotechnology to green and sustainable growth. In: Basiuk, V., Basiuk, E. (Eds.), Green Processes for Nanotechnology. Springer, Cham. https://doi.org/10.1007/978-3-319-15461-9_15.

Singh, R.K., Murty, H.R., Gupta, S.K., et al., 2012. An overview of sustainabiltiy assessment methodologies. Ecol. Indic. 15 (1), 281-299. https://doi.org/10.1016/j. ecolind.2011.01.007.

Soeteman-Hernandez, L.G., Apostolova, M.D., Bekker, C., et al., 2019. Safe innovation approach: towards an agile system for dealing with innovations. Mater. Today Commun. 20, 100548. https://doi.org/10.1016/j.mtcomm.2019.100548.

Solanki, P., Bhargava, A., Chhipa, H., et al., 2015. Nano-fertilizers and their smart delivery system. In: Rai, M., et al. (Eds.), Nanotechnologies in Food and Agriculture. Springer International Publishing, Cham, pp. 81-101.

Sonnemann, G., Tsang, M., Schuhmacher, M., 2019. Integrated Life-Cycle and Risk Assessment for Industrial Processes and Products. CRC Press, Boca Raton. https:// doi.org/10.1201/9780429436949.

Sørensen, S.N., Baun, A., Burkard, M., et al., 2019. Evaluating environmental risk assessment models for nanomaterials according to requirements along the product innovation stage-gate process. Environ. Sci. Nano 6 (2), 505-518. https://doi.org/ 10.1039/C8EN00933C.

Stern, N., Stiglitz, J.E., 2017. High-Level Commission on Carbon Prices. 2017. Report of the High-Level Commission on Carbon Prices. World Bank, Washington, DC.

Tavernaro, I., Dekkers, S., Soeteman-Hernandez, L.G., et al., 2021. A. Safe-by-design part II: decision model for balancing safety and functionality in the different stages of the innovation process. NanoImpact (submitted).
Trianni, A., Cagno, E., Neri, A., et al., 2019. Measuirng industrial sustainability performance: empircal evidence from Italian and German manufacturing small and medium enterprises. J. Clean. Prod. 229, 1355-1376. https://doi.org/10.1016/j. jclepro.2019.05.076.

Trump, B.D., Keisler, J.M., Galaitsi, S.E., et al., 2020. Safety-by-desing as a governance problem. Nanotodaz 35, 100989. https://doi.org/10.1016/j.nantod.2020.100989.

Udo de Haes, H.A., Sleeswijk, A.W., Heijungs, R., 2006. Similarities, differences and synergisms between HERA and LCA —an analysis at three levels. Hum. Ecol. Risk. Assess. 12 (3), 431-449. https://doi.org/10.1080/10807030600561659.

Van Duuren-Stuurman, B., Vink, S.R., Verbist, K.J., et al., 2012. Stoffenmanager Nano version 1.0: a web-based tool for risk prioritization of airborne manufactured nano objects. Ann. Occup. Hyg. 56 (5), 525-541. https://doi.org/10.1093/annhyg/ mer113.

Walser, T., Meyer, D., Fransman, W., et al., 2015. Life-cycle assessment framework for indoor emissions of synthetic nanoparticles. J. Nanopart. Res. 17 (6), 245. https:// doi.org/10.1007/s11051-015-3053-y.

Warheit, D.B., McHugh, T.A., Hartsky, M.A., 1995. Differential pulmonary responses in rats inhaling crystalline, colloidal or amorphous silica dusts. Scand. J. Work Environ. Health 21 (2), 19-21.

Windisch, E., 2013. Driving electric? A financial analysis of electric vehicle policies in France. Statistical finance [q-fin.ST]. Ecole des Ponts ParisTech. Available at: https ://tel.archives-ouvertes.fr/tel-00957749/document.

Yan, L., Zhao, F., Wang, J., Zu, Y., et al., 2019. A safe- by- design strategies towards safer nanomaterials in nanomedicine. Adv. Mater. 31 (45), 1805391. https://doi.org/ 10.1002/adma.201805391.

Zalk, D.M., Paik, S.Y., Swuste, P., 2009. Evaluating the control banding Nanotool: a qualitative risk assessment method for controlling nanoparticle exposures. J. Nanopart. Res. 11 (7), 1685. https://doi.org/10.1007/s11051-009-9678-y.

Zalk, D.M., Paik, S.Y., andChase, W. D., 2019. A quantitative validation of the control banding Nanotool. Ann. Work Exposures Health 63 (8), 898-917. https://doi.org/ 10.1093/annweh/wxz057.

Zimmerman, J.B., Anastas, P.T., Erythropel, H.C., et al., 2020. Designign for a green chemistry future. Science 367, 397-400. https://doi.org/10.1126/science.aay3060. 